\title{
Publishing \& the Book in Africa: A Literature Review for 2016
}

\author{
Hans M. Zell \\ hanszell@hanszell.co.uk \\ Copyright (C) Hans Zell Publishing Consultants 2017
}

This is the second in a series of annual reviews of select new literature in English that has appeared on the topic of publishing and book development in sub-Saharan Africa.

The previous annual literature review, for the 2015 period, can be found at https://www.academia.edu/20432811/Publishing_and_the_Book_in_Africa_-

_A_Literature_Review_for_2015. (Print version published in The African Book Publishing Record 42, Issue 1 (March 2016): 11-37 https://doi.org/10.1515/abpr-2016-0003.)

Extensively annotated and/or with abstracts, the present list brings together new literature published during the course of 2016, a total of 164 items. Also included are a small number of articles and other documents published in 2015 or earlier, and which have not hitherto been included in the Publishing, Books \& Reading in Sub-Saharan Africa online database (see also below). The literature review covers books, chapters in books and edited collections, journal articles, Internet documents and reports, theses and dissertations, interviews, audio/video recordings and podcasts, as well as a number of blog postings, with their posting dates indicated. Newspaper articles are not generally included, unless of substantial length or of special significance.

Records are grouped under a range of regional/country and topic-specific headings. It should be noted that, for the most part, literature on particular topics, e.g. children's book publishing, copyright, educational and schoolbook publishing, digital publishing, reading culture and reading promotion, etc. is listed under topic/subject rather than country headings. However, in the absence of a country index you can search for all country-specific records by using the Ctrl+F 'find' function in this document. For example, typing in 'Ghana' in the search box will find any text/records (in titles of articles, blog postings and other documents, or if part of the annotations) containing the word Ghana.

For more information on scope and type of material covered, consult the introductory pages (print or online) of Publishing, Books \& Reading in Sub-Saharan Africa: A Critical Bibliography at http://www.hanszell.co.uk/pbrssa/intro.shtml. 
Most journal articles published online are freely accessible unless otherwise indicated as being behind a paywall and subscription based. For web documents and electronic journals the date the source was accessed is indicated [in square brackets].

If I have missed any articles/papers, books, theses, or other relevant documents on the topics covered by this literature review (and published or posted in 2016), I would be grateful if these could be brought to my attention. Please email details to hanszell@hanszell.co.uk, together with an electronic file of the document, or a link to it.

All these records, and many more, will shortly be integrated into the online database of Publishing, Books \& Reading in Sub-Saharan Africa, which is currently in the process of migrating to a new hosting institution, Kwara State University Library in Nigeria (see also press release at http://www.hanszell.co.uk/Press\%20release.pdf). Unfortunately, due to a number of technical issues relating to metadata mapping and software functionality, there have been some delays in the migration of the database, but it is now hoped that it can be relaunched during the early part of 2017, on a more dynamic, Drupal-based open source content management platform. The first batch of updates and over 300 entirely new records will then also be added to the database.

Meantime the old database - current as at October 2014 and containing 3,062 records remains freely accessible at http://www.hanszell.co.uk/cgi-bin/online/pbrssa.shtml.

This pre-print version uploaded on Academia.edu 14 February 2017.

Print version to appear in The African Book Publishing Record

Volume 43, Issue 2, (June 2017) https://www.degruyter.com/view/j/abpr 


\section{Contents}

REFERENCE \& BIBLIOGRAPHY 5

GENERAL \& REGIONAL STUDIES $\quad 6$

Africa: General studies/Book history in Africa $\quad 6$

Regional studies: Africa, East $\quad 14$

Regional studies: Africa, Francophone $\quad 15$

$\begin{array}{ll} & 16\end{array}$

Note: most articles or blog postings on particular topics or areas of the book trade, for example publishing for children, publishing in African languages, copyright, scholarly publishing, etc. are classified under STUDIES BY TOPIC, see below.

$\begin{array}{ll}\text { Cameroon } & 16 \\ \text { Kenya } & 17 \\ \text { Namibia } & 18 \\ \text { Nigeria } & 18 \\ \text { Rwanda } & 23 \\ \text { Senegal } & 23 \\ \text { South Africa } & 25 \\ \text { Tanzania } & 29 \\ \text { Uganda } & 30 \\ \text { Zimbabwe } & 31\end{array}$

STUDIES BY TOPIC $\quad 32$

The acquisition of African-published material $\quad 32$

African books in the international market place 33

Authors and publishers/Publishing of African writers and African literature

(in Africa and elsewhere) 33

Book and journals assistance and donation programmes 36

$\begin{array}{ll}\text { Book prizes and awards } & 39\end{array}$

Children's book publishing $\quad 39$

Copyright and legal deposit/Authors' rights $\quad 41$

$\begin{array}{ll}\text { Digital media and electronic publishing } & 42\end{array}$

$\begin{array}{ll}\text { Educational and school book publishing } & 47\end{array}$

Journals and magazine publishing $\quad 54$

Mass market and popular literature publishing 56

Open access publishing and licensing $\quad 57$

$\begin{array}{ll}\text { Publishing in African languages } & 61\end{array}$

$\begin{array}{ll}\text { Reading culture and reading promotion } & 62\end{array}$

$\begin{array}{ll}\text { Scholarly publishing (General) } & 67\end{array}$

$\begin{array}{ll}\text { Scientific, technical and medical publishing } & 71\end{array}$

$\begin{array}{ll}\text { Women in African publishing/Publishing by and for women } & 72\end{array}$ 
BOOK INDUSTRY TRAINING/SELF-PUBLISHING

$\begin{array}{ll}\text { Articles and reports } & 73\end{array}$

$\begin{array}{ll}\text { Training manuals and resources } & 73\end{array}$

$\begin{array}{ll}\text { Handbooks for authors and self-publishing } & 74\end{array}$ 


\section{REFERENCE \& BIBLIOGRAPHY}

Higgs, Coleen, and Aimee Carelse, eds. African Small Publishers' Catalogue 2016.

Rondebosch, South Africa: Modjaji Books, 2016 (distr. outside Africa by African Books

Collective Ltd, Oxford). 118 pp.

This is the third edition of a useful directory that aims "to present a showcase of the variety and extent of independent and small publishing in Africa." It lists a total of 61 publishers, including some publishing services, each entry providing full address details, email address, telephone, website, principal contact person, and an image of their logo, together with short, informative profiles describing the activities of each publisher, nature of list and/or focus of its publishing programme, overseas distributors (where applicable), and more. It also contains six short articles, including "African Books Collective: 25 Years of the best in African publishing" by Justin Cox, and "Book Dash, growing new readers in South Africa" by Arthur Attwell.

Publishers' Association of South Africa PASA Directory 2016. Guide to Publishing in South Africa. Fish Hoek: Publishers Association of South Africa, 2016. 304 pp.

Includes the PASA membership directory and index of publishers, their imprints and agencies, and also contains an overview of all sectors of the South African publishing industry and the most recent Industry Annual Survey, which details income per sector, in print and e-books, production profiles by genre and language and educational sales by province. Additionally it includes a directory of training providers and industry-related bodies, including government department contacts, as well as listing of book fairs, book promotional events, conferences and other industry-related events.

Note: The PASA membership directory can also be accessed online at http://www.publishsa.co.za/members. Click 'List All', and then click on to names of individual publishers, with company profiles, key personnel, and full contact details and links to websites.

Zell, Hans M. Publishing \& the Book in Africa: A Literature Review for 2015. https://www.academia.edu/20432811/Publishing_and_the_Book_in_Africa__A_Literature_Review_for_2015[01/03/16] (Pre-print version)

Also in The African Book Publishing Record 42, no. 1 (March 2016): 11-37. [Published as "Reference Resources. Publishing and the Book in Africa - A Literature Review."] http://www.degruyter.com/view/j/abpr.2016.42.issue-1/abpr-2016-0003/abpr-20160003.xml?format=INT (subscription based/pay per view) [30/04/16]

The predecessor of the current (2016) literature review, which reviews select new literature in English that has appeared on the topic of publishing and book development in Africa published during the course of 2015. It covers books, papers in edited collections, journal articles, Internet documents and reports, interviews, as well as a number of blog postings Includes 85 records, most extensively annotated, and grouped under a range of regional/country and topic-specific headings. 


\section{GENERAL \& REGIONAL STUDIES}

\section{Africa: General studies/Book history in Africa}

\section{African Books Collective Ltd Read African Books.}

http://www.readafricanbooks.com/ [14/12/16]

A sub-site of the African Books Collective website http://www.africanbookscollective.com/, Read African Books "offers a place where people can come to read about the latest books, news, reviews and comment, on African publishing." It is intended "to help grow awareness of the issues affecting African books and publishing - to celebrate its diversity - and to increase the visibility of African books worldwide." ABC welcomes views or comments to publish on these pages. Initial contributions to the 'Comments and Opinion' pages include those by James Anderson, Walter Bgoya, Mary Jay, Stephanie Kitchen, Francis Nyamnjoh, Paul Tiyambe Zeleza, and Hans Zell, as well as a number of articles which first appeared in The African Writers Handbook, published by ABC in 1999 http://www.africanbookscollective.com/books/the-african-writers-handbook.

Bush, Ruth and Madhu Krishnan "Print Activism in Twenty-First-Century Africa." Wasafiri 31, no. 4 (December 2016) [issue 88]: 1-2.

http://dx.doi.org/10.1080/02690055.2016.1216267 (free access) [10/12/16]

This is the introduction to a special and very rich issue of Wasafiri, exploring the continuities and discontinuities in activist print cultures in Africa and the African diaspora. Its initial spark was the fiftieth anniversary of the UK's first black bookshop and publishing house, New Beacon Books (founded in London in 1966), and it aims to signal pathways that link from this and other important heritage initiatives to current trends in African and African diasporic book publishing. The articles and interviews brought together here seek to supplement an already burgeoning body of work on the topic by mapping and investigating the contemporary African publishing landscape.

Note: articles and interviews this special issue of Wasafiri pertaining to publishing in sub-Saharan Africa are individually abstracted and recorded in this literature review.

Carré, Nathalie "From Local to Global. New Paths for Publishing in Africa." Wasafiri 31, no. 4 (December 2016) [issue 88]: 56-62.

http://dx.doi.org/10.1080/02690055.2016.1216282 (subscription based, pay per view) [09/12/16]

Another (slightly longer) version at https://hal-inalco.archives-ouvertes.fr/hal-01389097/document (freely accessible) [11/11/16] Historically, the writing, selling, and reading of books have been a central means through which stories have been shared across borders. However, despite the wide-ranging nature of print, the author says, "in Africa, books and publishers still struggle to get their share of attention. Not only is the volume of African book production dramatically underrepresented in the world but the African publishing industry has also had to contend with the ongoing legacies of former colonial monopolies. At the same time, if printing books and selling them across national borders has always been one of the main stumbling blocks to the African publishing trade, then it is reasonable to think that the new technologies and media that have emerged at the turn of the millennium might enable the written word to travel more 
easily across the continent and beyond, expanding the reach and circulation of African publishing, and African knowledge today." The author examines some of these issues, as well as issues of uneven trading relationships, the relationship between local and global, publishing in African languages, and new opportunities for publishing and readership now offered by digital media. "New technologies seem to offer a real opportunity for publishing in Africa, but will that lead to more diversity or, on the contrary, a reign of global standardisation? The question is still open."

Emelife, Jennifer On Publishing Business in Africa: Emma Shercliff.

http://www.praxismagonline.com/cassava-republic-press/ (Posted 08 April 2016) [10/04/16]

This talk with Emma Shercliff of Cassava Republic Press http://www.cassavarepublic.biz/ is the final one in a series of insightful interviews with a number of small independent publishers in Nigeria, Rwanda, Senegal, and Uganda (see individual entries under Country Studies), and published in the lively Praxis Magazine for Arts and Literature http://www.praxismagonline.com/tag/publishing-in-africa/. This interview addresses some of the most frequently mentioned issues and challenges in the interviews: For example, on the price of books and how it affects the young African reader: Shercliff says "I think it is partly about perception. Young people may well be prepared to spend 1000 Naira on phone credit to chat to their friends, but baulk at paying the same price for a novel. However, we do try and price our titles as sensitively as possible." Commenting on the quality of books published in Africa she says there two separate issues here: "The first is the poor quality of physical production; the second is poor editorial control. Unfortunately, the quality of printing within Nigeria is not always of a high a standard or as consistent as we would like it to be. .... For this reason, we now print outside the country." In terms of improving editorial quality of books "the answer is simple: more publishers need to introduce rigid editing processes, including multiple checks and proofing. ... We work very closely with our authors to ensure that each finished work is a product of which they and we can be proud, but this process is expensive and time-consuming, which is why some publishers sometimes circumvent it."

On the many challenges of distribution, Shercliff says one of the major issues with distribution in Nigeria (and elsewhere in Africa) is that retail outlets do not pay publishers in a timely fashion. "Authors are understandably upset when they visit a bookstore and don't find copies of their books there, but if the bookshop owes a publisher a large amount of money, the publisher simply can't supply more stock without receiving payment. We have had several examples of bookshops and distributors who have gone bankrupt or disappeared altogether without paying for books - such instances make it difficult for publishers to have faith in the book distribution network." Meantime the book-buying individual has been hampered in the past by the high cost of delivery. In terms of distribution elsewhere on the continent, intra-African distribution remains problematic due to the high cost of transportation, customs and import tariffs, and the unreliability of the road network. "Somewhat counter-intuitively, it will be easier and more cost-effective for us to use our UK office to distribute our African-authored titles into East and South Africa, rather than ship them to other African countries from Nigeria."

Despite the myriad number of problems "publishing in Africa has come a huge way in recent years. Although the large educational publishers still dominate the industry, there are 
a number of young, dynamic companies across the continent publishing contemporary fiction and non-fiction and providing outlets for African-based writers."

Jay, Mary African Publishing in a Globalised World.

http://www2.su.se/media/videoplayer/videoplayer3.html?source=rtmp://stream-prod-

flash1.it.su.se/vod/mp4:16212001.mp4\&type=vod (Video 1hr20mins) [30/11/16]

http://www.readafricanbooks.com/opinions/african-publishing-in-a-globalised-world

(Text of lecture) [13/12/16]

Mary Jay, former CEO of African Books Collective, presents the annual Adam Helms Lecture for 2016 held at Stockholm University on 21 November. Her lecture discusses international publishing connections in the context of wider co-operation for development, digital or otherwise, and also touches upon issues of cultural independence, and how that impacts in Africa. She sets out a brief history of globalization as a context to independent African publishing, provides an overview of colonial and post-independence African publishing, talks about the genesis and activities of African Books Collective, the role of partnerships and assistance, and reviews the current challenges and prospects for African publishing in the digital age. The lecture is followed by a discussion with members of the audience.

Jay is critical of two of the British multinational publishers who have recently been involved in corruption scandals, and says the multinationals "take the lion's share of the textbook market in Africa, invest little, if any, of those profits within the country in which they are made; and the non-textbook sector is insufficiently developed by indigenous publishers, partly because of their long effective exclusion from the textbook market." A further continuing and deleterious activity, she says, are overseas book donation programmes and book aid charities that are shipping millions of free books to Africa every year. As a result "governments do not have to finance and resource libraries, including university libraries, if books are donated free, often irrespective of their relevance. Very few of these organizations match requested needs; rather they send publisher or library over-stocks. The shipping costs of the containers sent could in fact pay for locally published books requested by libraries in Africa .... What sort of charity is that, holding back a self-sustaining publishing industry, and continuing to swamp local culture by imported books?" On the topic of adoption of globalization opportunities, IT and the digital revolution, Jay believes that these developments have brought significant opportunities and benefits; and a great plus for African publishers has been digital marketing, enabling them to widely disseminate their print and e-books through the myriad mechanisms. On the negative side of globalization, Jay says "given our understanding that globalization broadly breaks down barriers, we might expect that there would be very much more cooperation between African publishers and the international publishing community. I am sorry that there is not a great deal of evidence of such cooperation."

Kamau, Kiarie, and Kirimi Mitambo, eds. “Coming of Age. Strides in African Publishing.

Essays in Honour of Dr. Henry Chakava at 70." Nairobi: East African Educational Publishers, 2016. 318 pp. (distributed outside Africa by African Books Collective Ltd., Oxford)

The sixteen chapters in this book form a Festschrift in honour of Henry Chakava, the distinguished Kenyan publisher, who is widely recognized as one of the continent's most 
dynamic and most innovative publisher, as well as being a prolific author of numerous articles and studies on many aspects of publishing and the book sector in Africa. Preceded by a foreword by Walter Bgoya - another icon among African publishers - the first five chapters in the book are tributes to Chakava's work, his commitment, courage and vision, and assess his intellectual and professional contribution to publishing and book development in Africa, as well as his involvement in the African world of letters. These five chapters are: "The Guru of Publishing: Assessing Henry's Chakava's Contribution in Africa" by Kiarie Kamau; "Henry Chakava: The Gory and Glory of African Language Publishing" by Ngũgĩ wa Thiong'o; "The Triangle that Defined AWS: Nairobi - Ibadan - London" by James Currey; "Publisher and Intellectual: The Work of Henry Chakava" by Simon Gikandi; and an orature epic in prose poetry commemorating Henry Miyinzi Chakava's 70th birthday, "African Orature: Back to the Roots" by the Kenyan writer and scholar Micere Githae Mugo. The subsequent eleven chapters - abstracted and listed as individual records in this 2016 literature review - focus on different areas of African publishing, containing chapters on scholarly publishing, copyright, publishing in the digital age, African books in the international market place, professional training, and the need for research and documentation on the book industries.

\section{Kitchen, Stephanie African Books and Knowledge Production.}

http://www.readafricanbooks.com/opinions/http-www-internationalafricaninstitute-org (Posted 01 October 2016) [19/10/16]

Reports about a number of sessions - organised in association with the African Books Collective - held at the 2016 African Studies Association (UK) biennial conference, which explored the challenges of publishing in Africa, and in relation to African studies in the North. The sessions included presentations by a number of leadings scholars and publishers, and issues discussed included the dissemination of print and electronic books between African countries, university presses in Africa, open access publishing, distribution challenges, the lack of library budgets and the negative effects of book donation programmes, debilitating import taxes on books, piracy, and how to redress the publishing imbalances between Africa and the North.

MacPhee, Josh Judging Books by Their Covers [African presses and magazines]. http://justseeds.org/channel/judging-books-by-their-covers/ [30/09/16]

Judging Books by Their Covers is Josh MacPhee's ongoing series of writings and image collections of book covers from many parts of the world. He says: "Although sometimes they feel marginal today, books have been a primary form of information and cultural exchange for almost 400 years. Book covers are often a person's first contact with the ideas inside, and in the hustle and bustle of contemporary life, cover designs are even more likely to shape the opinions of those that pick them up since many of us are too busy to ever read the entirety of the books. Judging Books by Their Covers largely focuses on - but is not exclusive to - the book covers and design coming out of the Left."

This interesting and often fascinating series now also covers the output of a number of small presses in sub-Saharan Africa, at this time most of them for the period of the 1970s through to the early 1990s (although "small press Africa" here also includes the branches/affiliates of two UK multinational publishers operating in Africa.) Each posting includes notes, insightful descriptions, critical commentary and observations about artwork and design, and 
sometimes a bit of historical background, together with images of the covers (and cover art credits/attributes, where available), as well as full bibliographic information on each book. A number of posts also include reproduction of some pages of text and illustrations.

Below are the links to the image collections of the book covers from African publishers that are thus far available:

no. 197: Ghana Publishing House [Corporation], Accra/Tema (posted October 2014)

http://justseeds.org/jbbtc-196-ghana-publishing-house/

207: Zimbabwe Publishing House, Harare http://justseeds.org/jbbtc-207-zimbabwe-

publishing-house/ (posted January 2015)

219: Éditions CLE, Yaoundé http://justseeds.org/219-editions-cle/ (posted October 2015)

225: Small Press Africa, part I, [Southern Africa, 1970s/1980s]

http://justseeds.org/225-small-press-africa-part-i/ (posted December 2015)

226: Small Press Africa, part II, [Nigeria and Ghana, mostly 1970s to 1990s]

http://justseeds.org/226-small-press-africa-part-ii/ (posted January 2016)

227: Small Press Africa, part III [Nigeria Yearbook 1969] http://justseeds.org/227-small-pressafrica-part-iii/ (posted January 2016)

228: Small Press Africa, part IV [East Africa, mostly 1970s/1980s] http://justseeds.org/228small-press-africa-part-iv/ (posted February 2016)

229: Small Press Africa, part V [East African Literature Bureau/Kenya Literature Bureau] http://justseeds.org/229-small-press-africa-part-v/ (posted February 2016)

230: Small Press Africa, part VI [South Africa/Southern Africa, mostly 1980s/1990s]

http://justseeds.org/230-small-press-africa-part-vi/ (posted February 2016)

239: Ravan Books [Press], Johannesburg http://justseeds.org/239-ravan-books/ (posted June 2016)

241: Black Orpheus. Journal of African and Afro-American Literature, Ibadan

http://justseeds.org/241-black-orpheus/ (Posted August 2016)

242: Mbari Publishing, Ibadan http://justseeds.org/242-mbari-publishing/ (posted

September 2016)

Nyamnjoh, Francis "Shared Visions and Challenges in Publishing in Africa: Henry Chakava and CODESRIA." In Coming of Age. Strides in African Publishing. Essays in Honour of Dr. Henry Chakava at 70, Nairobi: East African Educational Publishers, 2016, 159-188.

A contribution to a Festschrift in honour of Henry Chakava, this is both a tribute to Chakava's long-time devotion to the cause of publishing and the book in Africa, as well as a history of the work and activities of the Dakar-based Council for the Development of Social Research in Africa (CODESRIA), who have been in the forefront of African scholarly publishing for over four decades. The paper includes a discussion about the much debated issue of the marginalisation of African language publishing, and the authors seeks to demonstrate how CODESRIA "has navigated, negotiated and sought to reconcile this challenging linguistic landscape in the interest of its mission." In his observations about the state of the book industries in Africa, Nyamnjoh - in contrast with other contributors to the volume, who are rather more upbeat about progress in recent years - conveys a rather gloomy picture: "Well over 90 per cent of books published in Africa are school textbooks, and the majority of these are published by multinational companies." He asserts that, in South Africa for example, "publishing of books of interest and relevance to the majority of Africans is rare", but it is a claim that publishers in South Africa, especially the smaller 
progressive publishers, would probably wish to challenge. In the social sciences, Nyamnjoh says, "where objectivity is often distorted by obvious or subtle ideology, African scholars face a critical choice between sacrificing relevance for recognition or recognition for relevance, the politics of the cultural economy of publishing prevents them from achieving both recognition and relevance simultaneously."

\section{Nyariki, Lily "Lobby for the Book: The Politics of African Publishing and the Growth of}

Professional and Trade Organizations." In Coming of Age. Strides in African Publishing. Essays in Honour of Dr. Henry Chakava at 70. Nairobi: East African Educational Publishers, 2016, 217-235.

Online pre-print version at

https://www.academia.edu/24617767/Lobby_for_the_Book [13/05/16]

An overview of the African publishing scene over the past few decades, providing a broad historical perspective of the publishing industries in sub-Saharan Africa. It sets out some of the main challenges and problems facing the industry - notably the lack of government support, and the absence of robust national book policies - and "critically examines the nature and form of the politics surrounding African book publishing industries and provides the justification for lobbying." This is followed by a survey of the activities of the major book trade organizations and book promotional bodies in Africa (albeit several of them now dormant, or shut down), as well organizations and initiatives outside Africa that have supported the indigenous African book industries over the years. In her conclusion the author states that "a sustainable book industry that continuous to flourish is only possible with deliberate government support that recognizes the strategic importance of publishing and demonstrates this in its official commitment through policies and budgets."

Shercliff, Emma "African Publishing in the Twenty-First Century." Wasafiri 31, no. 4 (December 2016) [issue 88]:10-12 (Introduction), 13-22 (Questionnaire responses).

http://www.tandfonline.com/doi/full/10.1080/02690055.2016.1216270 (Introduction, subscription based, pay per view) [09/12/16]

Jay, Mary, and Emma Shercliff "A Survey of Fourteen African Publishers."

http://www.tandfonline.com/doi/full/10.1080/02690055.2016.1216272 (Questionnaire responses, free access) [09/12/16]

Introduces a survey, gathered by means of questionnaires and interviews, of fourteen wellknown independent publishers based across the African continent (from Cameroon, Kenya, Nigeria, Tanzania, South Africa, Uganda, Sierra Leone, and Zimbabwe), publishing primarily in English and African languages, as well as a number of recorded longer interviews (see entries by Raphael Thierry, p. 15) with four francophone African publishers. The survey intends to offer "a glimpse of the energy surrounding current African literary production in English, French and in African languages", as well as drawing attention to the many challenges the book industries face. Each publisher was asked to respond to 14 questions, which included a kind of 'mission' statement about each imprint, date founded, size of the company and staff employed, the number of women in management roles, the nature of the list and/or areas of specialization, number of new titles published annually, bestselling titles, interaction with and assistance provided to authors, funding, methods of distribution and marketing, a whether digital technologies play a significant role in their operations, and each publisher's views on the prospects and priorities over the next five years. 
The publishers interviewed were:

Bibi Bakare-Yusuf, Ntone Edjabe, Elieshi Lema, Hilda Twongyeirwe, Ann N Athiyo, Eghosa Imasuen, Billy Kahora, Walter Bgoya, Colleen Higgs, Azafi Omoluabi-Ogosi, Osman Sankoh, Muthoni Garland, Akoss Ofori-Mensah, and Irene Staunton. The publisher interviews are accompanied by images of the logo of each publishing house.

Stringer, Roger "African Publishing in the Digital Age." In Coming of Age. Strides in African Publishing. Essays in Honour of Dr. Henry Chakava at 70, Nairobi: East African Educational Publishers, 2016, 187-200.

Looks back at the early development of indigenous publishing in Africa, how locally owned publishing companies were formed and how they progressed over the years, the major challenges they faced at the time, the organizations and bodies that supported the book industries, and the technology issues that began to dominate discussions about publishing in the early 21st century. The author finds that the current picture indicates, despite the opportunities now offered by these continuously evolving technologies, many African publishers have still not fully embraced the digital age to maintain or improve their position in the publishing world. Not many publishers have websites, and of those that do, they frequently don't work. However, not all African publishers are the same, and there is now a new generation of publishers on the continent fully comfortable with the technologies, who "are adapting their approaches to publishing to take advantage of the opportunities that are available in the digital age." These publishers "represent the future of African publishing, particularly in the general publishing and literary arena. They are building on the foundations laid by the now established African indigenous publishers, but are better placed to use the technologies and approaches required in the digital age."

\section{Wallis, Kate "How Books Matter: Kwani Trust, Farafina, Cassava Republic Press and the}

Medium of Print." Wasafiri 31, no. 4 (December 2016) [issue 88]: 39-46.

http://dx.doi.org/10.1080/02690055.2016.1220698 (free access) [11/12/16]

"Provides an insight into the ways in which African literature in English has been made material by a new inter-connected generation of publishers based on the continent." It sets out the publishing histories of three independent African publishers that "bring into view the ways in which, in a digital age, decisions about medium are critical to how texts are read, circulated and given meaning." The also provides an analysis of the structure, vision, and editorial policies of these three publishers; their engagement with authors and readers, how they reach their publishing decisions, and how they are trying to build a sustainable literary publishing business. It also describes what they are doing to make their books visible to potential customers, and their distribution and marketing methods.

\section{Zell, Hans M. “Indigenous Publishing in Africa - The Need for Research, Documentation,} and Collaboration." In Coming of Age. Strides in African Publishing. Essays in Honour of Dr. Henry Chakava at 70, edited by Kiarie Kamau and Kirimi Mitambo. Nairobi: East African Educational Publishers Ltd, 2016, 141-158.

https://www.academia.edu/24429073/Indigenous_publishing_in_Africa_the_need_for_res earch_documentation_and_collaboration (Pre-print version) [18/05/16]

Sets out the need for more systematic and more vigorous research and documentation, data gathering, and analysis of the African book sector. This should include, for example, 
compilation of publishing data and book production statistics, as important elements in measuring the growth and vitality of indigenous publishing in Africa today. The author also calls for more collaboration, knowledge sharing, and information and skills exchange within Africa; as well as the possible development of North-South links and partnership programmes, such as for example a programme to establish a North-South research group, a new research cluster or network bringing together suitable academic and research institutions in Africa, Europe, and North America. A final section offers some pointers for reinvigorating research, and possible forms of collaboration. A listing of university institutions in Africa with Departments of Book and Publishing Studies is included as an appendix (pp. 270-271).

The author says "it strikes me that, especially with the closure of APNET - which has deprived African publishers of a collective voice - there is now, more than ever, a need for solidarity among independent African publishers: to share experience and know-how, and leading to collaborative ventures and programmes. Many indigenous publishers in Africa share a great deal of common ground, and they all face the same formidable challenges to survive and prosper, and so more active collaboration and sharing of skills and expertise could be of mutual benefit." And in his concluding remarks he states "in the new digital era, with its demand for skills and knowledge, and at a time of unprecedented change and promise, more informal collaboration between African publishers, as one-to-one relationships, or alliances of small independent publishers, may well achieve a greater measure of success and sustainability than Pan-African or regional organizations hampered by cumbersome constitutional and administrative management structures."

\section{Zell, Hans M. "Review Article: African Publishing Coming of Age." Logos. Journal of the World Publishing Community 27, no. 3 (2016): 52-60.}

http://booksandjournals.brillonline.com/content/journals/10.1163/1878-4712-11112111 (subscription based/pay per view) [01/09/16] https://www.academia.edu/26872848/African_Publishing_Coming_of_Age._A_Review_Es say (Pre-print version, freely accessible) [10/07/16]

A book review essay of a Festschrift, Coming of Age: Strides in African Publishing, published in honour of Dr. Henry Chakava, the distinguished Kenyan publisher who is widely recognized as one of Africa's most dynamic and innovative publishers, as well as a prolific author articles and studies on many aspects of publishing and the book sector in Africa. The first five chapters in the book are tributes to Chakava's work, his commitment, courage and vision, and assess his intellectual and professional contribution to publishing and book development in Africa, as well as his involvement in the African world of letters. The subsequent eleven chapters ${ }^{1}$, which are reviewed in this essay, focus on different areas of African publishing, containing papers on educational and scholarly publishing, copyright, publishing in the digital age, African books in the international market place, professional training, and the need for research and documentation on the African book industries. In a concluding section the author examines the advances of the African book industries over the past three decades, the emergence of a new generation of small but enterprising African publishers, and the dramatic rise in self-publishing in the new digital age.

\footnotetext{
${ }^{1}$ Note: annotated records for these 11 chapters are also included individually in this 2016 literature review.
} 
van der Vlies, Andrew “The History of the Book in Sub-Saharan Africa." In Michael F. Suarez SJ and Henry Woudhuysen, eds. The Oxford Companion to the Book. 2 vols. Oxford: Oxford University Press, 2010, Vol. 1, 313-20.

http://www.oxfordreference.com/view/10.1093/acref/9780198606536.001.0001/acref9780198606536-e-0039 (free access)

Not new, but now freely accessible as part of OUP's monumental reference work The Oxford Companion to the Book - covering the book, broadly conceived, throughout the world from ancient to modern times - this is a useful condensed history of the book in sub-Saharan Africa. It is divided into six sub-sections: MS Cultures, The Impact of Slavery and Evangelism, West Africa, East and Central Africa, Southern Africa, and Book Production in Africa Today, albeit the latter consisting of just a single paragraph.

\section{Regional studies: Africa, East}

Ilieva, Emiliia, and Hillary Chakava "East African Publishing and the Academia." In Coming of Age. Strides in African Publishing. Essays in Honour of Dr. Henry Chakava at 70, Nairobi: East African Educational Publishers, 2016, 106-128.

Presents a round-up of knowledge production, academic publishing output (journals and scholarly monographs), and collaboration between academician and publishers over the last four decades or more, during which a vast and diverse corpus of scholarship was produced and made available both within the East African region and the wider world. However, the present situation reveals a plethora of challenges, the authors say. Many of these challenges have arisen as a result of underfunding and understaffing of universities, "their inadequate infrastructure, and the crisis of quality in teaching and learning. A new institutional culture has evolved whereby intellectual concerns have been displaced by financial and administrative exigencies. Under these circumstances, research and the standard of publications have declined." Frequent irregularity in the publication of local journals, and sometimes poor editorial standards, lead academicians to seek publication abroad, thus "weak journals become weaker through constant supply of weak submissions." On the positive side, research output in scientific publications has been on the rise over the last decade, with Kenya the leading nation in this area, and research impact in the region. University presses in East Africa (at Dar es Salaam, Nairobi, and Makerere), "have, on the whole, not fulfilled the 'lofty mission' of university presses the world over" to publish and disseminate the best possible scholarship. This, the authors argue, demands a change "that would revamp the collaboration between the academia and publishers and expand the creation and dissemination of knowledge in East Africa. This change must start with the producers of knowledge-the academicians. ... One major component in this task is to improve the quality of their publications." University presses, the authors argue, "need not endlessly lament their pecuniary troubles", while publishers need to become more demanding regarding the quality of the manuscripts they accept for publication. Academics and publishers must close ranks in order to create a more vigorous intellectual system of which publishing is very much an integral part. 
Tumusiime, James "Publishing in East Africa: A Close Examination of Uganda (19852015)." In Coming of Age. Strides in African Publishing. Essays in Honour of Dr. Henry Chakava at 70, Nairobi: East African Educational Publishers, 2016, 129-140.

James Tumusiime, founder of Fountain Publishers http://www.fountainpublishers.net/ in Kampala, offers a close history and analysis of publishing in Uganda in which he describes his efforts to strengthen local publishing capacity in the country, and the numerous obstacles and challenges he faced in setting up his own indigenous publishing house in 1988, in a country in which at that time the textbook markets were monopolised by wellentrenched UK multinationals. Although significant progress has been made in establishing an autonomous publishing industry, multiple challenges remain. These range from a poor reading culture, the government's "flip-flopping policies" as it relates to the book sector and textbook policies, an uncertain investment climate, a weak book chain, and the absence of high quality printing facilities.

However, there have been positive developments too. For example, locally-based publishers have moved beyond the traditional bookshops to seek outlets to get their books to the reading public. Most of the major supermarkets nowadays have book sections on different topics, including textbooks, and more and more places for selling books are opening. And with the expansion of the East African Community, when Burundi and Rwanda came on board and with the latter switching to an English curriculum, the East African publishing industry received a significant boost. Nonetheless, unclear government book policies makes it very difficult to predict the future success of the book industries, and this calls for a more favourable and transparent business environment, Tumusiime says, and for clarity of guidelines: "Publishing houses, the public and government agencies are all partners in this endeavour and must contribute in the debate on how to improve the sector. However, governments must provide the leading role by improving budgetary allocations to the improvement of school books supplies; and the research initiative climate that can ensure creativity among writers, [and] sensitise the public on the significance of literature and a good reading culture."

\section{Regional studies: Africa, Francophone}

Thierry, Raphaël “An Interview with Sulaiman Adebowale.” Wasafiri 31, no. 4 (December 2016) [issue 88]: 23-25.

http://dx.doi.org/10.1080/02690055.2016.1216639 (subscription based, pay per view) [11/12/16]

Thierry, Raphaël “Clé Publishing. An Interview with Marcelin Vounda Etoa." Wasafiri 31, no. 4 (December 2016) [issue 88]: 26-27.

http://dx.doi.org/10.1080/02690055.2016.1216640 (subscription based, pay per view) [11/12/16]

Thierry, Raphaël "Ganndal Publishing. An Interview with Mamadou Aliou Sow and Marie-Paule Huet."

Wasafiri 31, no. 4 (December 2016) [issue 88]: 32-33.

http://dx.doi.org/10.1080/02690055.2016.1216642 (subscription based, pay per view) $[11 / 12 / 16]$ 
A three-part series of questionnaire interviews with a number of prominent publishers in francophone Africa from Senegal, Cameroon, and Guinea. They cover a wide range of issues and questions, such as 'How did your career begin?' or 'What prompted you to get into publishing?', to questions about editorial policies, the number of manuscript proposals received annually, average print runs, what have been the most successful titles, and how is the business funded. How do the publishers interact with authors, how do they help them to develop their work, and how are books marketed and distributed? Are the publishers active in co-publishing with other publishers on the continent, or selling rights? Do digital technologies play a role? And what are the seen as the priorities for each publisher in the years ahead in terms of list development.

\section{COUNTRY STUDIES}

Note: most articles or blog postings on particular topics or areas of the book trade, for example publishing for children, publishing in African languages, copyright, scholarly publishing, etc. are classified under STUDIES BY TOPIC.

\section{Cameroon}

Nfah-Abbenyi, Juliana Makuchi, and Ambroise Kom "Francophone Cameroon Literature: A Conversation with Ambroise Kom." Tydskrif vir Letterkunde 53, no. 1 (January 2016): 3050 .

http://dx.doi.org/10.4314/tvl.v.53i1.3 (subscription based/pay per view) Also at http://www.scielo.org.za/pdf/tvl/v53n1/03.pdf (freely accessible)

Ambroise Kom is a distinguished Cameroonian literary critic. In this wide ranging and insightful conversation he talks about the evolution of Francophone Cameroon literature, and the interview also covers some ground about the history and current status of publishing in the country. For example about the role played by Editions CLE in the seventies and eighties and the turbulent 1990s - a period heavily dominated by government censorship - although CLE did not publish any books that were considered to be politically sensitive. Kom also talks about the creation and selection of government approved textbooks, and the distribution and importation of books, an area still largely in the hands of a major French multinational that enjoys a monopoly for the distribution of newspapers and books. The lack of a national book policy, and the absence of positive government support for the book industries, has created a highly unfavourable climate for the growth and survival of the small number of publishing houses that currently exist. "Publishing within our national boundaries is tough, selling books within our national boundaries is not easy either. Most books published by our own people are in the diaspora - old and new - in Europe, America; they publish and some of their books can get here, generally shipped by themselves." An indigenous and sustainable book industry is still a far way off, "the book industry in this country is not yet born. It is yet to exist because the conditions do not allow for it." 
Abrams, Dennis Kenyan Publishers Call for Zero VAT on Books. http://publishingperspectives.com/2016/08/kenyan-publishers-on-vat/\#.V7rGa_krJD8 (Posted 22 August 2016) [28/08/16]

Based on a news story first published in Kenya's Standard Digital News, reports about the appeal by the Kenyan Publishers Association to persuade the government to scrap the $16 \%$ VAT charged on books and make books tax-exempt. However the statement by the Kenya Publishers Association, as quoted here, "the practice all over Africa is that books are never taxed" is far from accurate. In fact an increasing number of African governments are taxing books - and in turn knowledge - through debilitating tariffs, value-added tax (VAT), or goods \& services tax (GST), (see also the analysis by the International Publishers Association, VAT/GST on Books and E-books: An IPA/FEP Global Special Report, 20 July 2015 http://www.internationalpublishers.org/images/news/2015/vat2015specialreportcorrected. pdf). For example, VAT in Kenya is 16 per cent as reported in the article, Mozambique 17 per cent, South Africa 14 per cent, and Tanzania 18 per cent. Ghana and Zambia charge GST of, respectively, 17.5 per cent and 16 per cent on e-books. Moreover, in September 2015, the Zimbabwean government imposed a punitive, short-sighted 40 per cent import duty on books, including educational books and textbooks.

International Publishers Association Kenya: VAT on Books is Harming the Quality of Public Education.

http://www.internationalpublishers.org/educational-publishing/education-publishingnews/402-kenya-vat-on-books-is-ruining-the-quality-ofeducation?tmpl=component\&print=1\&layout=default\&page (Posted 24 May 2016) [28/05/16]

An interview with David Waweru, Chairman of the Kenya Publishers Association http://www.kenyapublishers.org/. For years, Kenyan publishers have fought successfully to keep books VAT-free, before the government finally imposed the $16 \%$ levy in September 2013. Three years later, the country's publishing and bookselling industries - of which educational books represent $85 \%$ - have been decimated by the move, according to the Kenyan Publishers Association. Waweru says that VAT on books has sent legitimate sales plummeting and simultaneously driven piracy up so far that it is now "the bigger economy than the legitimate publishing industry". He also says that there is evidence that some rogue booksellers are selling pirated books to schools at lower, VAT-free prices. Meantime, recently announced plans to reform and centralize the nation's textbook distribution system is beset by accountability issues. The Kenyan bookselling business is unregulated, he says, "money going to schools has led to corruption and some head teachers colluding with rogue booksellers who end up not actually supplying the books, although money still changes hands." The long-term consequences will be very serious: "If you look at the national exam results of the last two years, it shows that in public schools there has been a decline each year in performance. Significantly, the worst performed subject is English language and the worst performed paper is English composition, and it's all pointing towards the fact that pupils don't have access to books and aren't reading." 
Gross, Daniel A. Bringing African Books Back Home.

http://www.newyorker.com/books/page-turner/bringing-african-books-back-home

(Posted 21 November 2016) [30/11/16]

This story in the New Yorker magazine reports about an exclusively online bookstore in Kenya, the Magunga Bookstore http://books.magunga.com/, dedicated to the promotion and distribution of Kenyan and African books. Launched in December 2015, it "stocks only African books" as a matter of policy, mainly fiction by contemporary African authors (both in conventional print format and as e-books), but also some non-fiction, children's books, comics, and books in Kiswahili.

\section{Matata, Lydia Kenyans Flock to Roadside Vendors Selling Cheap Secondhand Books,} Spur Reading Boom. https://globalpressjournal.com/africa/kenya/kenyans-flockroadside-vendors-selling-cheap-secondhand-books-spur-reading-boom/ (Posted 10 April 2016) $[15 / 06 / 16]$

Second-hand book stalls and pavement booksellers that primarily sell books published in the US and the UK (reportedly bought through traders who import them in bulk, although their sources are not revealed), nowadays dot many corners in downtown Nairobi. These stalls, known as Inama, or 'bend over' bookshops in Swahili, have been flourishing since 2013 when the Nairobi City County government started licensing newspaper vendors to sell old books. Reading advocates argue that the stalls help to promote a reading culture in Nairobi, but local publishers are concerned that their new books can't compete with the cheap second-hand books on sale by street vendors, and that it can have an adverse effect on sales of locally published books.

\section{Namibia}

Nekomba, Netumbo Namibia: The Publishing Game.

http://allafrica.com/stories/201511101224.html (Posted 10 November 2015) [16/03/16]

Some observations on the current publishing scene in Namibia, which is still heavily dominated by educational and school book publishing. However, some general books from small independent publishers are selling well despite Namibia's small reading population, with books about animals, children's books and young adult fiction doing particularly well, as do titles that have a tourist appeal, or have created worldwide demand in the international markets.

\section{Nigeria}

Anderson, Porter Nigeria's Bibi Bakare-Yusuf: 'Our Brand Is Growing'. http://publishingperspectives.com/2016/12/nigerian-publisher-bibi-bakareyusuf/\#.WEbbmrKLSpo (Posted 06 December 2016) [10/11/16]

An interview with the founder of Nigeria's Cassava Republic Press http://www.cassavarepublic.biz/ Bibi Bakare-Yusuf, in which she talks about present and future issues in African and West African publishing, and the many challenges ahead. In Africa, publishing involves doing everything yourself and there aren't formal distribution systems, she says, while "publishing in the West brings a new set of rigors and demands, given how structured and process-driven the business is. Perhaps the biggest challenge of 
publishing in Nigeria is "that it's close to impossible to find a consistently reliable local printer. After several disastrous experiences, we made the decision to print overseas." And that is not without its "challenges", as she delicately puts it, in terms of getting books through customs at the port once shipments arrive.

Many parts of Africa are currently suffering from an economic downturn, which inevitably affects purchasing power, and this is particularly the case with the Nigerian economy, which has suffered greatly from a dramatic recent slump in oil prices. Getting books to readers who want them in Nigeria and across Africa remains another challenge: "We don't have a reliable formal distribution system as there is in the West and we have very few decent retailers. We'll continue to have to expend a lot of resources and time getting our books to readers using salaried marketers traveling around the country. The lack of good bookshops to aid discovery and sales is still a problem." However these distribution challenges can be overcome by partnering with other non-bookshop outlets, persuading them to consider stocking selected books: "Cassava Republic partnered with supermarkets and cafes, and have even sold our books at hairdressers." Cassava set up an office in London in April 2016, and in early 2017 is planning to launch a list in North America.

\section{Bagnetto, Laura Angela Abuja-based Publishing House Cassava Republic Opens UK Office, Interview.}

http://www.english.rfi.fr/africa/20160120-abuja-based-publishing-house-cassava-republicopens-uk-office-interview (Posted 20 January 2016) [19/02/16]

Emma Shercliff, a director of the Abuja-based Cassava Republic Press http://www.cassavarepublic.biz/, explains why they are opening offices in Europe and talks about the growing popularity of their e-books. All of its titles going forward will be both in e-book as well as in print format. "People are going online and buying e-books, but our experience here in Nigeria is that the tendency is still to buy print in the first instance." The launch of the new UK operation is both for logistical reasons as well as to find a new audiences and new markets for its authors. "The business model is now signing authors for world rights, that we can now publish not just in Nigeria and Africa, but also in the UK. That's part of the model. But it's also just in terms of ease of distribution. Ironically, it's going to be much easier for us to publish into east Africa and South Africa out of the UK. The intra-Africa distribution channels are pretty cumbersome for print-issues with customs, tax, tariffs and barriers. It's costly, so the model is the really to become a global company. We'll still have Africa as our base, but will use the UK to get to other markets."

Emelife, Jennifer On Publishing Business in Africa: Eghosa Imasuen.

http://www.praxismagonline.com/on-publishing-business-in-africa/ (Posted 26 February) [03/03/2016]

Nigerian publisher Eghosa Imasuen of Kachifo Ltd http://kachifo.com/home/ (and its Farafina Books imprint) talks about establishing cordial relationships between young unpublished writers and their prospective publishers, their editorial and submissions policies, and the challenges and vagaries of the publishing business in Africa. "This industry is recovering from near-death. And there really is no arbiter of what makes it to the market. So there is a din in the market, a multiplicity of voices. The market will decide, and those who are left will improve. There is no process to this. Those who do good work will continue to do so, and the books will improve." 
Emelife, Jennifer On Publishing Business in Africa: Richard Ali. http://www.praxismagonline.com/parresia-books/ (Posted 07 March 2016) [09/03/16]

An interview with Richard Ali, Chief Operating Officer at Parrésia Publishers http://parresia.com.ng/ in Nigeria, in which he shares his opinion on the state of publishing in Africa and talks about the high costs of producing books, the need for the highest standards of production quality, the challenges of distribution, and how to improve relations between writers and publishers.

Emelife, Jennifer On Publishing Business in Africa: Su'eddie Vershima Agema. http://www.praxismagonline.com/tag/sevhage/ (Posted 13 March 2016) [18/03/16]

Su'eddie Vershima Agema is founder and Chief Executive Officer of Sevhage Publishers https://sevhage.wordpress.com/ in Makurdi, Benue State, Nigeria (and see also https://sevhagereviews.wordpress.com/. In this interview he speaks to Praxis Magazine about the steep price of African-published books as a result of high manufacturing costs, and reading habits in Nigeria (or the lack of it). He also talks about author-publisher relations and fair dealing with writers, the need for high editorial and production quality standards, and effective marketing strategies.

Fick, Maggie “Publisher's Expansion Brings Nigerian Writers to World Stage." Financial Times 27 November 2016

https://www.ft.com/content/8cebd6d6-79b4-11e6-97ae-647294649b28 (Posted 27 November 2016) $[29 / 11 / 16]$

Reports about the activities of Cassava Republic Press http://www.cassavarepublic.biz/, the Nigerian publishing house that opened a subsidiary in London in April 2016. Cassava Republic is stated to be "the first ${ }^{1}$ African publisher to open a subsidiary outside the continent". To Cassava Republic's Bibi Bakare-Yusuf the London launch provides a different approach of tapping other African markets that are hungry for literature from across the continent. Ironically, she explains, "it is easier to enter markets such as Kenya from the UK than it is from Nigeria because the distribution links between London and Nairobi are stronger than from Abuja." Production is another challenge of doing business in Nigeria. While the books for sale in the British market are manufactured in the UK, Cassava Republic has always printed its books for the Nigerian market abroad, mainly in India, and imported them. This is because manufacturing locally is fraught with many uncertainties, including unreliable electricity and transport. An integral part of their publishing vision, Bakare-Yusuf says, "is publishing a diverse range of authors who are exploring topics well beyond conflict, rural life and some of the other themes for which the genre is best known."

\footnotetext{
${ }^{1}$ Note: that is a claim that is not entirely accurate. Quite apart from the fact that the not-for-profit, African-owned African Books Collective Ltd has been doing the marketing and distribution for a very large number of African publishers from its Oxford base since 1989, this 'first' must probably attributed to the late Nigerian publisher and journalist Raph Uwechue, who set up his Africa Books Limited in London in the 1990s, publishing a series of major reference resources on Africa. Earlier, another Nigerian, Joseph (Joe) Okpaku, was the President of Third Press in New York in the 1970s (publishing in the areas of African studies and African literature), as well as having a presence in London and in Lagos operating as Third Press International.
}

Ihebuzor, L.A. and Ihebuzor, N.A. "The Political Economy of the Publishing Industry in Nigeria." Open Access Library Journal, 3 (2016), e2674. http://dx.doi.org/10.4236/oalib.1102674 $[15 / 10 / 16]$ 
Explores the political economy of book publishing in Nigeria, and examines practices in the book publishing industry and the various forces that influence the decisions made by the established Nigerian book publishers to accept or reject a manuscript for publication. The author argues that the drivers for most of these decisions are largely socio-economic and political and that unless checked, these drivers could distort the basic values of books, which are to promote the sharing of knowledge and cultural products for the development of a nation. "The bottom line of any [publishing] business is profit"; and there is no evidence of social responsibility. "What is on display in decisions to publish or not to publish is actually the power of economic considerations to determine the fate of cultural products and to shape and filter what is produced and consumed in these domains of culture and learning." The article identifies a number of the barriers that tend to exclude manuscripts by authors with low status and power from the lists of the of the major and well-established book publishing houses, and examines possible coping strategies for such excluded writers, including self-publishing, and the challenges that these pose. In their conclusion the authors declare: "A nation is as progressive as its book industry. A book industry is vibrant to the extent it allows unfettered access to all those who are willing and able to produce useful manuscripts. Realities that exclude persons who are willing and able from access to this industry are a disservice to any nation. Actions taken to level the playing field and which allow the 'under-privileged' manuscript author access to the world of published persons will thus not only be useful at the individual psychological level, but would also have socially salutary effects on national development."

\section{Okpamen, Ehidiamhen Struggles of a Startup: Bringing Back the Books.}

http://thenerveafrica.com/7934/rovingheights-bringing-back-books/ (Posted July 24 2016) [06/08/16]

An interesting interview with Tobi Eyinade, co-founder of Roving Heights (RH Books) in Nigeria http://rhbooks.com.ng/, a "socially minded book sales and distribution company with the focus of making books the new cool", in which she talks about their experience and challenges of managing this new start-up business, what hinders the growth of startups in Nigeria, and about Nigerians' attitude to reading. In addition to marketing and selling books through its online platform as well as brick and mortar book stores, RH Books aims to enrich the reading culture in Nigeria through literacy programmes and various interventions that will help to create a vibrant reading public.

\section{Penn, Joanna African Authors and Diversity in Publishing. With Tolulope Popoola.} http://www.thecreativepenn.com/2016/02/22/diversity-in-publishing-african-authors/ (Podcast and text, posted 22 February 20016.) [15/05/16]

A talk with Tolulope Popoola - author of flash fiction, romance, and short stories, and founder of Accomplish Press http://www.accomplishpress.com/ - about African authors and Nigerian publishing. How she got started with blogging and writing and moved into self-publishing; and about issues such as being labelled 'ethnic fiction', diversity issues in publishing, how publishing currently works in Nigeria, how Nigerian readers find books and read digitally on mobile and devices, the type of books that are currently most popular, new e-book platforms, and book marketing both at home and abroad. In Nigeria, Popoola claims, "traditional publishing is almost non-existent. There are very few publishing houses willing to take a chance on new fiction writers, hence the rapid rise of self-publishing among writers in Nigeria." 
Rossetti, Chip At Abu Dhabi Book Fair: A Few Words with Nigeria's Richard Ali. http://publishingperspectives.com/2016/04/richard-ali-parresia-nigeriapublishing/\#.VyNmkPkrJD8 (Posted 29 April 2016) [02/05/16]

Nigerian publisher and writer Richard Ali of Parresia Publishers http://parresia.com.ng/, the company he founded in 2012, talks about the multiple hurdles faced by those working in publishing in Africa. Distribution remains a major challenge for the majority of African publishers, he says; and publishers will have to be creative about distribution: "Increasingly, we are looking for ways to test the markets for our books, and often those ways involve a digital platform."

Shercliff, Emma The Changing Face of Nigerian Literature.

https://www.britishcouncil.org/voices-magazine/changing-face-nigerian-literature (Posted 09 December 2015) [16/02/16]

A look at Nigeria's vibrant and changing literary landscape: How Nigerian-based publishing houses are providing an outlet for new writers, how Nigerian authors are choosing to write for Nigerian audiences, and how publishers are seeking to reflect authentic voices from the African continent. The literary landscape in Nigeria is changing, Shercliff says, "the conversation about Nigerian writing, and, more widely, African writing, is taking place on the continent, without affirmation from the West." She also reports that one of the leading independent publishers in Nigeria, Cassava Republic Press http://www.cassavarepublic.biz/, in a reversal from the traditional model, has announced plans to establish a base in London from which to publish and distribute African authors; and that publisher Bibi Bakare-Yusuf plans to bring Nigerian writing to the UK, strengthening the bonds between the two publishing landscapes, but without taking away the autonomy of Nigerian writers and publishers. "A lack of distribution networks and myriad logistical challenges such as customs charges, poor road networks, and the high cost of transportation have until now prevented printed books from being more widely distributed out of Nigeria. Establishing a base in London will open up possibilities of distributing more titles more widely, including to East and Southern Africa."

\section{Uche, Anthony Ogbonna "Stakeholders' Perspectives on Book Publishing and Marketing} in Nigeria." Communication Panorama. African and Global Perspectives 1, no. 2 (NovemberDecember) 2015: 1-23.

http://rex.commpan.com/index.php/cpagp/article/viewFile/41/40 [06/08/16]

Book publishing should be considered an essential enterprise in any nation, the author says. However the Nigerian book industry has been bedevilled by numerous issues, ranging from a weak infrastructure to inadequate skilled manpower, and piracy and violation of copyright. This article traces the history of the publishing industry in Nigeria, identifies some of the major challenges confronting it, and examines the opportunities for growth and development. 


\section{Rwanda}

Emelife, Jennifer On Publishing Business in Africa: Louise Umutoni.

http://www.praxismagonline.com/huza-press/ (Posted 26 February 2016) [09/03/16]

Jennifer Emelife speaks with Louise Umutoni, founder and director at Huza Press http://huzapress.com/, a Rwanda-based publishing house committed to developing quality creative writing, and the growth of the creative industry through the publishing and distribution of contemporary African writing. She talks about the challenges of distribution within Africa, utilization of the Internet as distribution platforms, the promise of e-books, and the lack of online payment systems. "Our goal at Huza Press is to work with at least one publishing house in every region to either republish for us, or serve as a distribution point for our books. E-publishing is another solution that some publishers are looking at, but lack of online payment systems pose a hindrance to this ....We don't have reliable online payment systems and mobile money is not cross-cutting. There are a few platforms that have been set up to sell African content such as Nuntu http://nuntu.hehelabs.com/, but they are still grappling with creating a reliable payment system. I think that once we address the payment system issue then we will start to see a lot more use of the Internet as a distribution platform."

\section{Senegal}

Emelife, Jennifer On Publishing Business in Africa: Sulaiman Adebowale. http://www.praxismagonline.com/amalion-publishing/ (Posted 10 March 2016) [11/03/16] Sulaiman Adebowale is the director of Amalion Publishing http://www.amalion.net/en/, a Pan-African publishing house based in Dakar, Senegal, producing books both in French and in English, and publishing authors from many parts of the continent as well as the diaspora and elsewhere. In this interview he talks about the challenges facing African publishers, the harsh realities of the economics of publishing, new approaches of promoting writers and their books, his views on self-publishing, and about the digital engagement with readers. Adebowale disputes the still common notion that most African books are poorly produced: "I don't know any publisher on the continent or outside who will deliberately set out to produce anything but excellent books. The more money and time you have to put into the production processes, the better the end result. But the money invested means you may have to print more copies to sell and more money to market and distribute in order to even think of breaking even." And, he asks, just how much are readers willing to pay to buy books, whether regularly or even just occasionally?

On self-publishing, he says some authors have been successfully doing this, but most have not, just as much as some publishing ventures have been successful, while others have failed. "It is the way of the world. Specifically for the African book market, the rarity of successful self-published books could be one of the reasons why we are having this discussion in the first place. The writers have yet to come up with better published and marketed titles on their own." There is plethora of platforms and social media outlets for African writers to express themselves and get their work published and shared, but "how does a writer get noticed in this avalanche of writings online? How do you make your literature stand out from the drivel of writings out there?" 
On the digital side and e-books, Adebowale says that there are now several publishers on the continent active in this area but "the key question is still on the market and the earnings, when will this side be a good ROI [Return-on-Investment]? If the e-commerce platforms develop further in most African countries and not just a few, there can be better leverage there. And we can also think of doing something much more interesting and engaging with e-books rather than simply just selling the plain vanilla e-pub and Kindle files. Secondly, most publishers still have work to do about creating content for mobile phones, which is the dominant digital platform in our part of the world."

Emelife, Jennifer On Publishing Business in Africa: Mamadou Diallo.

http://www.praxismagonline.com/tag/mamadou-daillo/ (Posted 17 March 2016) [21/03/16]

Founded in 2009, Les Éditions Vives Voix http://www.vives-voix.com/ is a Dakar-based fine arts and photography publisher and retailer, and at the same time acts as a not-for-profit organization that aims to develop and promote arts and culture, as well as organizing lectures and exhibitions, concerts, and other cultural events. In this interview with Mamadou Diallo, in charge of its non-fiction list, he offer his views on the publishing situation in Senegal, including issues such as editorial capacity, problems of intra-African distribution, publishing opportunities for new writers, and about breaking language barriers in writing across African countries.

On the topic of editorial excellence he says "I think we must agree and take it as a fact that today, most of the books published are lacking quality. Most good Senegalese writers would rather be published elsewhere than in Senegal for many reasons including the quality of the editorial work. Good publishing comes from a qualified workforce that must have been trained, which makes it costly. As long as we don't have local publishers with a reach to global or, at least, continental markets that would allow for increases in business size, we won't be able to employ good and trained human resources." Distribution, similarly as editorial quality, "has a lot to do with financial strength and investment. If we are talking about literary fiction, I think there is a market wide enough to sustain good publishing, and that the market can grow bigger if we invest more in marketing, communication and specialized media." As for creating opportunities to promote new and upcoming writers, Diallo states "I think African publishers today must be more preoccupied by the emergence of new readers than by new names in literature. If we ensure that more Africans are excited about books and ready to pay for them, we'll have much more publishing opportunities for up and coming writers."

Radio France Internationale Crossing African Boundaries Through Books: Sulaiman Adebowale, Head of Amalion Publishing. https://soundcloud.com/radiofranceinternationale/crossing-african-boundaries-throughbooks-suliaman-adebowale-head-of-amalion-publishing (Radio broadcast, 4.07mins) [12/09/16]

RFI's Laura Angela Bagnetto speaks to the founder and head of Amalion Publishing, Sulaiman Adebowale. His Dakar, Senegal-based publishing house http://www.amalion.net/en/ aims to reach across Africa's colonial language divide to foster discussion by publishing academic texts and novels in both French and English. Adebowale explains Amalion's multilingual path, and the decision to work across languages, as a 
condition predicated on the situation of the continent. In order to broaden knowledge and understanding of Africa, discussions on Africa cannot be monolingual because the continent and its peoples are not: "We cannot restrict ourselves to the phony boundaries of Francophone, Anglophone, Lusophone, Arabophone Africa. If you don't work across the languages, you will end up losing the interesting stuff."

\section{South Africa}

Bosman, Nicolette "An American in Joburg Discovers a New World of Book Selling." http://www.editors.org.za/Documents/PEGboard\%20APRIL\%202016\%20final.pdf PEGBoard. Newsletter of the Professional Editors' Guild (April 2016): 18.

A short profile of Griffin Shea, "a journalist who walked the streets of downtown Joburg and discovered a whole new world of bookselling" - street booksellers and informal book vendors - and how he became immersed in this market. And which demonstrated that there is definitely a market for lower-priced books, which the sellers can offer by virtue of their much lower overheads.

Faircliff, Jessica "Jonathan Ball. A Rolling Stone Gathers no Moss." Bookmark 87 (Dec 2016Feb 2017): 22-23.

http://www.sabooksellers.com/wp-content/assets/BookmarkIssue87.pdf [28/12/16]

A profile of Jonathan Ball, http://www.jonathanball.co.za/ a leading publisher and distributor of English-language general books in South Africa, specialising in South African history, politics and current affairs, as well as publishing some fiction. In this interview he talks about when and how he started in the book business in 1976, the company's growth during the following years, how the publishing industry has changed over the years, and how he sees the future of publishing in South Africa.

Le Roux, Elizabeth "The Early Years of a Dutch Publisher in South Africa: A Case Study of Van Schaik in Pretoria." Image and Text, no. 25 (2015): 86-109.

https://www.academia.edu/19396551/The_early_years_of_a_Dutch_publisher_in_South_A frica_A_case_study_of_Van_Schaik_in_Pretoria [13/05/16]

Print culture came to South Africa with the Dutch East India Company, followed by the British colonisers. This influence persisted after colonisation officially ended, with the Union of South Africa in 1910. Many early publishers and booksellers were immigrants, especially Dutch immigrants. While the settlers were Dutch, many lent their support to Afrikaner nationalist causes. Illustrated with archival photographs, this article considers the implications of the colonial influence for the development of South African print culture, using a case study of Van Schaik Publishers, which was founded by a Dutch Immigrant, J.L. van Schaik, in 1914. Attention is paid to the question of how this early publisher saw its role in developing an 'imagined community' that engaged both with the culture of the coloniser and that of the developing settler colony. The author argues that Van Schaik played a significant role in the development of Afrikaans publishing, but that little scholarly attention has been paid to his publishing philosophy and strategy. "Van Schaik developed a highly successful business as both a bookseller and a publisher, largely thanks to print networks that already existed between South Africa and Europe, which he in turn further developed. The records suggest that Van Schaik was successful owing to both his ability to develop 
networks through the associations of family and political sympathies, and his attention to the details of his business. It is clear that Van Schaik gained an early understanding of the local market and tapped into a growing Afrikaner nationalist spirit, which was facilitated by acceptance into a fairly elite, professional network. It is difficult to disentangle business motives from the ideological motivation associated with the promotion of Afrikaans. ... An examination of Van Schaik's publishing philosophy and list shows that such early publishers played an important role in developing an 'imagined community', especially within the nascent Afrikaans community."

\section{Malec, Jennifer Facts and Fictions: Find out about Bridge Books - Joburg's Newest Independent Bookstore - and the Coming Reading Revolution.} http://bookslive.co.za/blog/2016/08/02/facts-and-fictions-find-out-about-bridge-booksjoburgs-newest-independent-bookstore-and-the-coming-reading-revolution/ (Posted 02 August 2016) [12/08/16] Griffin Shea talks about his plans for a newly opened store Bridge Bridge Books https://bridgebooks.co.za/, a unique bookstore in downtown Johannesburg, who believes in supporting African writers and in finding as many ways of getting books into the hands of as many readers as possible. Bridge Books work with other booksellers across downtown Johannesburg, acting as a go-between for publishers in South Africa and smaller retailers who might not have access to new books. Shea talks about distribution challenges, which he describes as being among the most daunting in his part of the world, and also how unaware local citizens seem to be of opportunities to buy books, because they only look for books in conventional bookstores, even though dozens of informal street vendors are selling books just around the corner. "When you walk around you realise there's a lot of reading happening that the formal book industry just doesn't know about." His ambition is to connect the publishing establishment with the reading that happens "quite literally on the street". But what are people looking for? Well, almost everything Shea says, while his younger customers are interested in lesser known liberation heroes, as well as early African or pre-colonial stories about the San or Mapungubwe. "They tend not to be so obsessed with the recent past, which weighs so heavily on many people. They want a much broader look at history, which is inspiring."

\section{Mulgrew, Nick uHlanga: On the Birth of a South African Poetry Press. \\ http://publishingperspectives.com/2016/01/uhlanga-birth-south-african-poetry- press/\#.VtmF3fmLRD8 (Posted 13 January 2016) [03/03/16]}

Nick Mulgrew discusses the poetry publishing scene in South Africa and the birth of his poetry press, uHlanga, that seeks to open doors for young poets to develop their careers, and specializes in publishing debut anthologies from the country's most promising young poets. Like other forms of literature locally, poetry is in the doldrums, Mulgrew says, and with a few exceptions, "commercial publishers don't do poetry, really. Few publish it, and even fewer publish it if it's not to do with textbooks or the school market." He hopes that his small new press will contribute to "make the literary industry in South Africa more equitable, more accessible and more interesting than it currently is." uHlanga publications are now available from the Oxford-based African Books Collective. 
Nishino, Ryota "Political Economy of History Textbook Publishing During Apartheid (1948-1994): Towards further Historical Enquiry into Commercial Imperatives." Yesterday $\mathcal{E}$ Today, no. 14 (December 2015): 18-40.

http://www.scielo.org.za/pdf/yt/n14/03.pdf [26/09/2016]

Also at

https://www.academia.edu/21814274/Political_economy_of_History_textbook_publishing _during_apartheid_1948-

1994_Towards_further_historical_enquiry_into_commercial_imperatives [26/09/2016]

The provision of textbooks in apartheid South Africa (1948-1994), a source of much controversy and media interest in recent years, is placed in historical perspective, with particular reference to the production of history textbooks. During apartheid bureaucratic structures and commercial imperatives gave rise to a conformist ethos that stifled innovation. The textbook approval and adoption processes led publishers into adopting strategies to ensure approval for and approval of their textbooks. To avoid friction with education departments, editors urged self-restraint on their writers and instructed them in how to write officially approvable manuscripts. Textbook approval and adoption processes at that time clearly indicate that the education departments during apartheid assumed and ensured a monopoly in textbook approval, as well as adoption policies and processes. Most manuscripts were approved on condition that specific changes were made. There was little opportunity for publishers or authors to challenge the departments' instructions for amendments.

In his conclusion the author states: "The use of honorary authors, in-house screening before submission, and the selection of co-operative or 'colluding' authors were among the strategies publishers and editors developed. Consistently rigid and tight timeframes not only stifled the development of textbooks of quality, but compelled writers to engage in de facto plagiarism of textbooks that had successful records in the selection and approval processes; the publishers acquiesced in and encouraged such practices. Combined with these constraints, the de facto price caps on the textbooks gave rise to an additional commercial concern for textbook publishers and one that compromised the educational concerns of the pupils and teachers. The nature and extent of these constraints engendered an ethos that encouraged and rewarded conformity rather than innovation amongst publishers and authors."

PEN South Africa Jacana Media's Bridget Impey on the State of Publishing and the Zapiro Litmus Test.

http://pensouthafrica.co.za/jacana-medias-bridget-impey-on-the-state-of-publishing-andthe-zapiro-litmus-test/ (Posted 25 November 2015) [16/02/16]

A thought-provoking talk given by Bridget Impey of Jacana Media (and previously with the prominent anti-apartheid David Phillip Publishers for many years) entitled "Overview of the publishing industry in South Africa: which specifics and which issues?", presented at the International Assembly of Independent Publishers held in Cape Town in September 2014, hosted by the Paris-based Alliance internationale des éditeurs indépendants/International Alliance of Independent Publishers, and held under the auspices of UNESCO. It provides an overview of the state of publishing in South Africa, examining book buying habits and the lack of a widespread reading culture, and the perceived reasons for it. "Locally written fiction is noticeable by its absence as it is the imported variety that sell. Cookbooks feature 
strongly, as does local memoir and local current affairs. Much of this top of the pops list is in Afrikaans." Books found on the bestseller lists are frequently the books that are not challenging. "It's harder to make the books that matter, the books that change things, that challenge us and which more properly reflect and expose the state of this state, thus revealing the state of the book. And one of the factors that militate against this kind of publishing is that it isn't always going to break even, let alone make a profit."

In the second part of her presentation Impey addresses the threats, or severe restrictions, to freedom of information, freedom of expression, and freedom to publish - faced by authors, artists, journalists, the media and publishers in South Africa. "The current methods of intimidation have been the extensive threat of defamation lawsuits. And it is an effective deterrent. 'Discretion is the better part of valour' is not a game changing war cry, but publishers regularly opt for the safer route, mindful that a court challenge issued by the state is likely to set one back a million rand before even setting foot in a court room. And that's without the collateral damage of time and effort tied up in the business of defending oneself. And which independent publisher can afford those kinds of costs?"

South African Book Development Council National Book Week 29 August to 6 September 2014. 2014 Final Report.

http://sabookcouncil.co.za/nationalbookweek/wp-content/uploads/2015/09/SABDCReport-2014.pdf [26/10/15]

National Book Week (NBW) was launched in 2010 and is a joint initiative between the South African Book Development Council and the Department of Arts and Culture (DAC). Since its inception in 2010, National Book Week is the longest running and most successful campaign of its kind to foster partnerships between government, the publishing sector, civil society and the media, to highlight and celebrate a reading lifestyle in South Africa. In 2014 the organizers were proud to introduce a travelling bus which, over seven days, transported NBW ambassadors, motivational speakers, authors, storytellers and a toy library to towns from Ganyesa in the North West Province to Paarl in the Western Cape. The annual National Book Week focuses on promoting the reading of books while showcasing local writers, poets, publishers, storytellers, booksellers and authors. The use of indigenous languages was again a strong element in the campaign, and was supported by the distribution of indigenous language books, made possible through the SABDC's Indigenous Languages Publishing Programme funded by the National Lotteries Distribution Fund. To determine the impact of NBW 2014, the South African Book Development Council focused on obtaining detailed feedback from the different hosts, which was achieved through a debrief session and a report questionnaire being distributed to all partners. The feedback is summarised in this report and clearly indicates the support for and interest in this annual event.

van Wyk, Andrea Local Publisher, Robin Stuart-Clark, Talks about Winning at the Bologna Children's Book Fair.

http://www.andtheplotthickens.com/local-childrens-imprint-wins-big-at-internationalbook-fair/ (Audio recording, 10:51mins [18/08/16]

Bumble Books http://www.printmatters.co.za/bumble_books/, the children's imprint of small South African independent publisher Publishing Print Matters, was the winner of the 'Best Children's Book Publisher of the Year in Africa' prize at the prestigious Bologna 
Children's Book Fair in 2016. The imprint provides a platform for new South African illustrators and authors to showcase their work internationally. This is an interview with the founder of Bumble Books, Robin Stuart-Clarke, during which he talks about the progress South African children's authors and illustrators have been making in recent years, and the challenges facing children's book publishing South Africa and the development of a lively reading culture in the country. For another story about the award see also (among others) http://imaginemag.co.za/?p=1748.

\section{Work/Life: Thabiso Mahlape \\ http://thisisaerodrome.com/worklife-thabiso-mahlape/ [20/03/16]}

Thabiso Mahlape is the publisher of BlackBird Books http://www.jacana.co.za/blackbirdbooks, an imprint of Jacana Media launched in August 2015 that seeks to provide a platform and a publishing home to both new voices and the existing generation of black writers and narratives. In this short interview she talks about developing this new list, her workspace, who and what has influenced her work, and "what is the hardest thing about your job", to which she answers "the uncertainty. Never knowing how the market will receive your product. Authors imagine they alone feel this angst, but it's worse for a publisher."

\section{Tanzania}

Languille, Sonia "The Scramble for Textbooks in Tanzania." African Affairs 115, no. 458 (2016): 73-96.

http://afraf.oxfordjournals.org/content/115/458/73.full.pdf+html (subscription based/pay per view) [12/09/16]

In 2014 the Chama Cha Mapinduzi (CCM) government in Tanzania decided to discontinue the market-based system for textbook provision that was established in the early 1990s and revert to full state control. Drawing on the theory of political settlements and the literature on Tanzania's industrial politics, this article "examines the political economy of textbook provision in this country in order to generate new insights into the relations between the educational, political, and economic spheres." The author demonstrates how donor ideology and practices, while subjecting textbooks to generic market principles, also promoted the interests of the major Western publishing corporations. She argues that the distribution of power within the state, and the ambiguous relations between the CCM ruling elites, bureaucrats, and the capitalist class, prevented the consolidation of an effective textbook policy geared towards supporting the local publishing industry. Finally, the article explores elites' diverse corrupt practices to capture public funding for textbooks at the national and local levels. Under Tanzania's country-specific political settlement, "the textbook sector, far from primarily serving educational goals, has indeed been reduced to a vast site of primitive accumulation."

\section{Masabo, Conrad John The Declining of the Reading Culture in Tanzania. A Case of the}

Institute of Adult Education. Saarbrücken, Germany: LAP/Lambert Academic Publishing GmbH \& Co. KG, 2015. 72 pp.

"The declining of reading culture among students of tertiary and higher learning and Institute of Adult Education (IAE) students in particular is alarming and threatening the realisation of a well-educated and learning society, the education vision of Tanzania 
Development Vision (TDV) 2025. Overreliance on lecturers' and tutors notes, reading for examination, poor tendency of individual reading, and total dislike of reading beyond the examination scope are among the major manifestation of the declining reading culture at the IAE. Claims are made by the IAE stakeholders as to the reason for this awful academic and 21st century culture among the students which include but not limited to unavailability of reading materials, limited infrastructure, and [an] education system and academic tradition that focuses more on summative evaluation and certification or examination passing. If not addressed, it may escalate and jeopardise the hopes of creating [a] learning society in Tanzania." [Not examined, publisher's blurb]

Strengthening Tanzanian Publishing (TZAP) Walter Bgoya. https://www.youtube.com/watch?v=uLvIGLZlA3o (Video 4:06mins) [31/12/15]

One in a series of short videos from the Elsevier Foundation's-supported Strengthening Tanzanian Publishing (TZAP) project, setting out the challenges and opportunities for academic publishing in Tanzania. In this video the project coordinators talk with Walter Bgoya of Mkuki na Nyota Publishers, about how the project could enhance reading and publishing culture in Tanzania. Bgoya says: "we have this idea that only with western standards is science possible. This is not correct. I think science is possible wherever people are looking for solutions to their problems." To strengthen Tanzania's scholarly culture, he sees a need to first develop a reading culture: "Books have not been accessible. People have not been introduced to reading when they are young, so that is a habit that has to develop." One of the outcomes of the TZAP project was to establish a consortium of academic publishers that brings them together in order that they can pool their resources. Bgoya says "there are now 20 universities in Tanzania and many more are coming. Every university wants to do two, three journals, [but] the resources don't really permit. I think it would be much better if several universities came together and produced one journal at a time together."

Strengthening Tanzanian Publishing (TZAP) Dr Mboera.

https://www.youtube.com/watch?v=FJL7-MEpVCc (Video 3:43mins) [31/12/15]

One in a series of videos from the Strengthening Tanzanian Publishing (TZAP) project, designed to improve scientific publishing in Tanzania. In this video the editor of the Tanzanian Journal of Health Research, describes the difficulties in academic publishing in the country, and stresses the important role of the government and other stakeholders in demanding evidence that will ultimately motivate scientists to publish. Weakness in communicating research is one of the main problems for academic publishing in Tanzania, and it is therefore vital to strengthening research networks focusing on research communication and knowledge translation.

\section{Uganda}

Byaruhanga, Catherine Uganda, Where a Book can Cost a Month's Salary. http://www.bbc.co.uk/news/world-africa-36230245 [10/05/16]

The author laments the high price of books in Uganda, despite fact that the country has a fairly robust local publishing industry. However, most publishers' main focus is on educational books and school texts rather than creative writing. Meantime, with the advent 
of social media and wider availability of the Internet, reading for pleasure is in steep decline. The author says Uganda appears to be caught in a Catch-22 situation. "People seem to read more when they have the money and know the value of reading for personal success. But to make decent money, it helps to be educated and able to read."

\section{Emelife, Jennifer On Publishing Business in Africa: Crystal Rutangye.}

http://www.praxismagonline.com/moran-publishers/ (Posted 24 March 2016) [30/03/16]

Crystal Rutangye, who is shortly to set up her own publishing company, reflects on the publishing situation in Uganda, and issues of marketing, editorial capacity, production quality, the challenges of distribution, the publisher's role in promoting new and upcoming writers, and publishing in African languages. "The book publishing industry in Uganda is still dominated by the academic [i.e. educational] book sector", she says, and production quality is still often poor: "A lot needs to be done to improve the quality of African books, beginning with professionalizing certain sectors of the book publishing chain. ... Publishers (and self-published authors) need to be ready to pay for excellent-quality editing; including paying for more and specialised editors to work on one book, and more umbrella bodies need to train editors and advocate for the professionalization of the field."

Speaking about new distribution platforms and the emergence of e-books, she states "common challenges with distributing e-books include the expensive Internet bundles in the country, poor technology-based infrastructure nation-wide, and general lack of understanding of the dynamics involved in selling, buying and reading e-books. Less than ten percent of Uganda's major book publishers and distributors deal in e-books." And talking about publishing in indigenous languages and overcoming language barriers, Crystal Rutangye says "I honestly cannot think of a way this barrier can be broken across Africa. It is a struggle even in Uganda where there are over 50 ethnic languages." While there is a measure of demand for books written in local languages, "there is a limit to the number of books in local languages that can be sold to particular communities; they cannot sell in other communities. The local language authors are essentially writing for a smaller group of people. Local language books are good for primary education, but for the whole publishing industry, it is currently more profitable to write [and publish] in languages that a larger group of people can identify with" (in Uganda, that would include the official languages: English and Kiswahili)."

\section{Zimbabwe}

Staunton, Irene "Publishing for Pleasure in Zimbabwe. The Experience of Weaver Press." Wasafiri 31, no. 4 (December 2016) [issue 88]: 49-54.

http://dx.doi.org/10.1080/02690055.2016.1216282 (subscription based/pay per view) [11/12/16]

Founded by Irene Staunton and Murray McCartney, Weaver Press http://weaverpresszimbabwe.com/ is a dynamic independent publishing house formed to publish books from and about Zimbabwe. Its growing fiction list now features over 120 Zimbabwean short story writers, and its novelists include several international prizewinners who were first published by Weaver Press. Its non-fiction list focuses on political and social history, the environment, media issues, and women and children's rights. The 
company was established in 1998, just prior to a major economic downturn and years of political challenges, hyperinflation, as well as rapidly declining public library services, most of them now without any funds for book acquisitions. Between the 1980s and the 90s substantial amounts of donor funding was received in the country to stimulate creativity and support initiatives in the book sector and indigenous publishing, one of them the Zimbabwe International Book Fair, which gained wide international attention and provided a vibrant focus for the whole book industry. However, "most of these hubs of activity have now closed or diminished to a shadow of their former selves. When donor support was withdrawn for various reasons, neither local associations nor government were able to provide the requisite financial backing."

This article describes the challenges of a small independent publisher struggling to survive, much less prosper, in a harsh economic climate and operating in hugely difficult trading conditions. It greatest challenge today remains the absence of a vibrant book-buying public, with reading primarily for examination purposes. Meantime years of economic hardship have taken their toll at both secondary and tertiary levels, and photocopying is rife. Irene Staunton says that small general publishers everywhere will need to take stock and consider whether and how they still have relevance. If they continue to rely on book sales alone they may not survive. New opportunities have now opened up with the advent of the e-book, and that it is possible that the e-book will provide a bridge to reach new readers, Staunton says: "However, if there is no substantive tradition of reading or buying books, with the exception of small professional elites, can we expect that people will buy a short story to read on their cellphones, even if it costs no more than a dollar?" She continues, "it will be a long time before every child in Zimbabwe has access to a computer or an e-reader, so physical books will remain important for the foreseeable future. The challenge for us and the education system as a whole is to ensure that students read beyond the curriculum and continue reading into adulthood."

\section{STUDIES BY TOPIC}

\section{The acquisition of African-published material}

van de Bruinhorst, Gerard Library Acquisitions Trip to Lagos and Ibadan, 23 April-14 May 2016.

\section{http://www.ascleiden.nl/news/library-acquisition-trip-lagos-and-ibadan [20/07/16]}

Gerard van de Bruinhorst, an information specialist at the African Studies Centre Library in Leiden, went on a book acquisition trip to Lagos and Ibadan and bought well over 1,000 books for the ASC Library. This is a short but interesting account of his trip. He visited publishers and bookshops and found the supply overwhelming, with over a thousand books and journals (none of them available in any Dutch library), and approximately 300 titles not yet catalogued by any of the 10,000 Worldcat libraries. Even so, it became clear that the Nigerian publishing industry has been hit hard as a result of the economic meltdown caused by the sharp drop in oil prices. Topping the list of books published were publications on Nigerian politics, followed by literature and linguistics, together with an astonishing number of biographies and autobiographies. 


\section{African books in the international market place}

Jay, Mary "Internationalising the African Book." In Coming of Age. Strides in African Publishing. Essays in Honour of Dr. Henry Chakava at 70, Nairobi: East African Educational Publishers, 2016, 201-216.

Mary Jay provides an informative account of the raison d'etre that led to the establishment of the not-for-profit, African-owned African Books Collective Ltd (ABC) http://www.africanbookscollective.com/, its mission, governance, and finance, and its evolution and wide range of activities over the years since it first started trading from Oxford in 1989. Initially supported by a range of donor agencies for a number of years, a major remodelling of ABC took place in 2007, when it became self-financing, and moved to a largely digital model at the same time. In 2015 it celebrated its 25th year of trading, and currently acts as a worldwide marketing and distribution outlet for 2,500 print titles and ebooks (scholarly, literature, and children's books) from over 150 African publishers in 24 countries. These twenty-five years have not all been plain sailing, "it took endurance to build up to the self-sufficiency of the last eight years, with times of financial strain, and anxiety as to $\mathrm{ABC}$ being able to pay its way month to month", but it remains committed to its ethos to strengthen African publishing through collective action and to increase the visibility and accessibility of the wealth of African scholarship and culture. Internationalising the African book remains a huge challenge, Jay says: "The needs remain to engage with Northern scholars, to counter negative perceptions, and to stand on an equal footing with publishers worldwide. Problems may still be faced by indigenous publishers in Africa with enduring unconducive policies; but they are not constrained in internationalising their books. The digital age has greatly enhanced the opportunities, and that remains $\mathrm{ABC}^{\prime}$ s mission."

\section{Authors and publishers/Publishing of African writers and African literature (in Africa and elsewhere)}

Bush, Ruth, and Ali Hussein African Connections at New Beacon Books. Wasafiri 31, no. 4 (December 2016) [issue 88]: 3-8.

http://dx.doi.org/10.1080/02690055.2016.1216268 (subscription-based, pay per view) [09/12/16]

An insightful interview and conversation with Sarah White, New Beacon Books co-founder (with the late John la Rose), and Ali Hussein, a long-standing friend of New Beacon and founder of Griot International Books. It expands upon the history of radical print activism in Britain through a particular focus on New Beacon's connections to writers in Nigeria, Kenya, South Africa, Ghana, and Sudan. Ngugi wa Thiong'o, Biodun Jeyifo, Kole Omotoso, and the Sudanese poet Sirr Anai Kelueljangwere among prominent African writers published under the New Beacon imprint.

Conteh-Morgan, Miriam Weaving Other Anansi Webs: Developing the Electronic Literary Map of Africa.

https://www.academia.edu/1449952/Weaving_Other_Anansi_Webs_Developing_the_Elect ronic_Literary_Map_of_Africa [16/12/16] 
Sets out some of the constraints that African literary production continues to face in trying to reach a wide audience, and looks at the possibilities electronic publishing may offer to help meet the challenges. In particular, it describes how an electronic resource currently being developed by the author, "one whose main objective is to help bridge the various divides that exist between creative writers and their audiences", could provide a possible solution. The author describes how this searchable bio-bibliographical web resource, the Literary Map of Africa https://library.osu.edu/literary-map-of-africa is being developed, including aspects such as user viewpoints on contents, content aggregation and enhancement, as well as database development. The database hopes to serve multiple purposes, and aims to pull together the geographically scattered voices of writers, and give equal space to canonical writers on the one hand, and those struggling to reach wider audiences on the other, thus offering users a more panoramic view of the African literary landscape. The author says: "As a library-based initiative whose main objective is to offer free access to information in the pursuit of learning, it will further chip away at the stranglehold of commercial publishing gatekeepers, and secure another foothold for libraries in the publishing arena."

\section{Dro, Edwige-Renée Why is Translation Important? Publishing African Literature Across} Languages.

https://africainwords.com/2016/11/07/why-is-translation-important-publishing-africanliterature-across-languages/ (Posted 07 November 2016) [12/11/16]

A contribution from a four-day workshop held in August in Kampala that was set up with the aim of giving 35 aspiring and early career arts managers and entrepreneurs in the African literary and cultural scene the opportunity to build market knowledge, develop project management skills, share best practice, and network with colleagues from across the continent. Each day of the workshop focused on ways of setting up, thinking about and sustaining a different kind of literary initiative. As part of a session on 'Publishing Translations', Ivorian writer and translator Edwige-Renée Dro, among others, spoke about their experiences of working to publish writing across languages and shared reflections on the aesthetics, practicalities and driving forces behind the different initiatives they've been involved in; and what do writers and publishers value in the translation process and how does that impact what writing gets published in translation, and where.

\section{Edoro, Ainehi Interview: Laura Murphy of Modern African Writers Series Talks African Publishing.} http://brittlepaper.com/2016/02/interview-laura/ (Posted 08 February 2016) [15/05/16] An interview with Laura Murphy, who is the series editor of Ohio University Press's 'Modern African Writers Series', consisting of novels, memoirs, and other literary works that aim to showcase the most talented writers of the African continent. The series also features works of significant historical and literary value translated into English for the first time. In this interview Murphy offers some interesting observations on how global trends intersect with African writing, and also talks about their collaboration with African publishing houses to get their books to a global audience. Asked whether there are parallels with Heinemann's famous African Writers Series (AWS) and Ohio's new series, Murphy says "we are certainly similar to AWS in our goal of bringing new voices to print. Our approach is a bit updated, and we hope to publish a new generation of writers who may depart from their fathers' conventions (as good children should) to chart out new territory." 
Ohio University Press is partnering with African publishers Kwani? http://kwani.org/ and Farafina/Kachifo http://kachifo.com/home/ to simultaneously publish books that will be available in the US and in West and East Africa, sharing submissions and agreeing on titles, and market the books together. "We are committed to publishing books that matter, that breathe air into conversations, that represent fresh and critical perspectives. We do that best when we're collaborating with folks who are in the mix - writing, reading, publishing in Africa." While thrilled to be able to get authors access to audiences both in the US and in Africa, "what we don't want is to compete with these exciting presses for authors, or for authors to have to choose whether they get exposure on the continent or in the US. That should be an unnecessary choice."

Fatunla, Dele Meiji Africa Writes: The Next Generation and the State of Play. http://newafricanmagazine.com/africa-writes-next-generation-state-play/ [10/09/16] A round-up of the current state of play in African literature publishing, and the emergence of a new generation of digital publishers and writers across the continent. Although there have been some exiting developments, "the modern conundrum for African writers remains because the primary consumer market for writers remains the West, or more broadly speaking, it is international, rather than on the continent." However the picture may change soon, the author says, and which might well make it more profitable to be a successful writer on the continent than in the West: "the size of markets like Nigeria, South Africa and Kenya dwarves the publishing markets in the UK and elsewhere, if the challenges of distribution can be met." The author also suggests that "publishers in Africa are increasingly waking up to the possibility of African literature in indigenous African languages being a huge market opportunity for them." Moreover, and importantly, African writers are increasingly putting their support behind African publishers by publishing first on the continent. There is a genuine revolution happening in African publishing, Fatunla says, "it is driven by increased digital access across the continent, both in the form of blogs, and publishers, who are making it easier for new African voices to emerge that have no need to be linked to the market demands of the West."

However, if African writers want to replace the West with Africa as their primary audience, there is still a lot of work to be done. Meantime, what everyone is trying to figure out is "whether Africa can resolutely become its own source of validation and the main market for its own literature. The obstacles still remain formidable, but increasingly African writers and publishers have the tools and are ready to do the work, and the economics and demographics of the continent are on side."

Manyika, Sarah Ladipo Betting on Africa. An Essay.

http://brittlepaper.com/2016/03/betting-africa-sarah-ladipo-manyika-

essay/\#sthash.brZ81qQw.dpuf (Posted 28/03/16) [10/04/16]

Extracts also published in Publishing Perspectives

http://publishingperspectives.com/2016/04/betting-on-africa-cassava-republic-

nigeria/\#.VwdqzvkrJD8 [10/04/16]

Sarah Maniyka sets out the reasons behind her decision to publish her second book with an African publisher rather than one from the West. She published her first novel In Dependence with Legend Press in London in 2008. Like many debut authors, she granted world rights to her publisher, who subsequently sold African rights to a Nigerian publisher (and Weaver 
Press in Zimbabwe also published an edition in 2015.) "I hadn't realized that African publishers are almost always at the very end of rights negotiations. They must buy, rather than sell, the rights to books, even those that are marketed to the rest of the world as 'African' stories. I have long bemoaned the fact that Africa has a history of not owning the rights of production or distribution, but I never fully realized the extent to which this was also the case in publishing." In publishing her latest work with an African imprint, she says "I am betting on my Nigerian publisher because they've proven themselves over time to be savvy and diligent custodians of my work whose proficiency and attention to detail put many of their British and U.S. counterparts to shame. This is an important point to make in a world where many people assume that things are always better done in the West than in Africa." By a happy coincidence she completed her second book, Like a Mule Bringing Ice Cream to the Sun, in the year that her Nigerian publisher, Cassava Republic Press http://www.cassavarepublic.biz/ decided to open a UK branch. Thus her work will be published in Nigeria first and shortly thereafter in Britain.

Manyika, Sarah Ladipo Why I Chose an African Publisher Over a Western One. https://www.theguardian.com/books/booksblog/2016/apr/20/why-i-chose-an-africanpublisher-over-a-western-one (Posted 20 April 2016) [20/04/16]

[Note: This seems to be another version of the preceding record]

Sarah Ladipo Manyika, a black Briton of Nigerian origin living in the US, and a Cassava Republic http://www.cassavarepublic.biz/ author (now with a presence in the UK) states that in her experience "African publishers are more savvy and look outside clichéd representations of the continent's writers." Some people expressed scepticism about her decision to work with an African publisher, yet her experience outweighed any sense of risk: "My first book was published by a British publishing house, which then sold the Nigerian rights to Cassava, who proved themselves savvy and diligent custodians of my work. Moreover, unencumbered by some of the stereotypes of what so-called 'African literature' should look like, they were able to think creatively and offer fresh ideas on everything from book jackets to marketing strategies." Her second book, a novella entitled Like a Mule Bringing Ice Cream to the Sun, was published with Cassava in April 2016 and she says "the arrival of Cassava Republic Press in the UK is an important moment in the history of publishing. I am proud to rely on one of Africa's trailblazing publishers to bring us new names and new stories that will enrich and expand the world's literature."

\section{Book and journals assistance and donation programmes}

Faulkner, Jessica Rebuilding Communities Through Reading.

http://www.bookbrunch.co.uk/article_free.asp?pid=rebuilding_communities_through_rea ding (Posted 18 November 2016) [29/12/16]

Jessica Faulkner reports on Book Aid International's work in getting books to refugee camps and those living in prisons. For the estimated half a million people living in Kenya's two largest refugee camps, life can be hard. Kakuma and Dadaab refugee camps were established in the 1990s, and many of their inhabitants have been living there ever since. The camps have developed informal infrastructure such as schools, hospitals and markets, but resources such as books are still very hard to access. It is vital for people, especially children, to be able to continue with their education while living in the camp. Book Aid International 
supplies books to the Dadaab and Kakuma refugee camps through its partner Windle Trust Kenya, which runs educational programmes in the camps. In the summer of 2016 it also partnered with French publishing giant Hachette on its 'Book for a Book' campaign, which seeks to raise awareness of the plight of refugees and provide them with new books. And it recently signed a partnership agreement with Norwegian NGO A Drop in the Ocean, which is supporting refugees in Chios, Greece, and has sent an initial shipment of 1,000 books that will support a library set up in the camp by the NGO. Most of these books will be for children, thus providing a chance for them to continue reading and learning.

Leonard, Fiona My Close Encounter with Literary Colonialism.

http://www.fionaleonard.net/2016/09/my-close-encounter-with-literary.html (Posted 10 September 2016) [30/12/16]

Fiona Leonard offers some interesting thoughts here about the potential negative effects of book donation programmes on the local African book industries: "Filling a library in Ghana with books from overseas may have benefits for readers but it's a disaster for the local publishing industry. Imagine the challenges of trying to sell a book in a country with over $50 \%$ illiteracy. Take out the people who can't afford to buy your book, who aren't interested in your book, or who would rather buy something from overseas, and you're going to be struggling to be commercially viable. Now add to that mix a deluge of books from overseas - including those donated by well-meaning international organizations - and things are looking grim." In some countries in Africa a need may well remain to bring in books from the outside, "but we should be looking into communities first to see what's there, to see what can be nurtured and grown, before we start reaching overseas."

\section{Lubuto Library Partners Supporting African Publishers.}

http://www.lubuto.org/october-2016 [04/11/16]

Well-intentioned though they might be, large-scale book donation programmes may not always be the most effective solution to meet book needs in Africa. Individually tailored and recipient request-led schemes, specially curated shelf-ready library collections, or other forms of support, such as financial support for shipping costs, or assisting libraries and schools with the purchase of books by local authors and publishers to the greatest extent possible, may well be more appropriate. Some of these smaller projects and initiatives have demonstrated a rather more enlightened approach to the whole area of 'book giving' than the big book aid players, who rarely seem to be overly concerned about the state of the African book industries, much less supporting them. One of these smaller organizations is Lubuto Library Partners http://www.lubuto.org/ that works in partnership with other NGOs and community-based organizations to build libraries and library networks in Zambia. Supporting African publishers is part of their mission, and this is what they had to say in their October 2016 newsletter, in which they describe some ways how Lubuto has recently supported local and regional publishers: "Libraries thrive when publishers thrive. Whether they produce paper books or e-books, a robust publishing industry is necessary for the educational and intellectual life of a society. The progress of African publishers and booksellers has been impeded in recent years by well-meaning external book donation programs from wealthy areas."

Lubuto also stresses the importance of librarians evaluating donated materials by the same criteria as materials being purchased for library collections, and that a strengthened local 
publishing industry supports literary expression and consumption. "A good and effective library always pays close attention to developing a balanced and appropriate collection; it can't be 'given' to them from an external source. Beyond the library perspective, the development of local publishing inspires local people to become authors and illustrators and greatly increases access to affordable books among children and youth."

\section{Plonski, Patrick Providing Books for Schools and Libraries in Africa: What Is the Impact on Literacy?}

https://www.booksforafrica.org/assets/documents/SanFranciscoAfricanStudiesAssnpaper Nov10.pdf [26/06/16]

A paper presented at the African Studies Association's 53rd annual meeting in San Francisco in November 2010 (and now made accessible online on the Books for Africa website). The author is the Executive Director of the major US book donation organization Books for Africa, and the purpose of his analysis "was to determine if usage of donated Englishlanguage text and library books had a positive effect upon literacy in Africa." He discusses projects that provide books and educational materials for school and community library use in Africa, and assesses the impacts of such projects on literacy objectives established by the UN Millennium Development Goals. Best practices, cost-effectiveness, literacy benchmarks, and funding mechanisms are also discussed. Case studies from Tanzania and Liberia are analysed, as well as findings from projects in some of the 43 other African countries served by programmes of this type. Finally, the author makes a number of recommendations for the future success and good practice of book donation projects in Africa. Plonski concludes that, provided that proper conditions are established, "donated books provided from Western sources did improve literacy rates and learning in a number of locations studied. Additionally, it was found that a perception of benefit exists in many of the schools and communities served through these book donation programs"; and that the implications of his analysis are "that book donation programs of the type used in this analysis do positively impact economic development in the developing world. In short, books promote literacy, which promotes education, which promotes rural and urban economic development."

There are, however, some quite contentious views in this paper: For example in support of his argument in favour of English-language donated books Plonski states: "To systematically use local tribal languages for school instruction in Africa would require the preparation of educational materials in some 800 languages (Gordon, 2005), hence the use of English and other world languages for government, commerce, and education across Africa. The costs of producing books and other educational materials in local languages at the primary, secondary, and post-secondary levels may be cost-prohibitive, even when theoretically possible (World Bank, 2002). Additionally, strong evidence exists that the people of Africa want Western-language textbooks." Moreover, the author makes no mention at all, in the case studies or elsewhere, about the activities of African publishers; nor is there any discussion of the potential negative consequences of overseas book donation programmes on the local publishing industries. 


\section{Zell, Hans M. Book Donation Programmes Revisited.}

http://www.readafricanbooks.com/opinions/book-donation-programmes-revisited [14/11/2016]

"Book Donation Programmes for Africa: Time for a Reappraisal? Two Perspectives" is a two-part study in English and in French published in African Research \& Documentation. Journal of SCOLMA - the UK Libraries and Archives Group on Africa, no. 127 (2015) [publication delayed, published 2017]: 3-137 (part I), 139-215 (part II). This is a summary of the study, with extracts from its conclusions, and as well as offering some further thoughts on the topic. Pre-print online versions of the full study are freely accessible at Academia.edu at the links indicated below (and see also Publishing $\mathcal{E}$ the Book in Africa. A Literature Review for 2015.)

Part I: Book Donation Programmes in English-speaking Africa, by Hans M. Zell https://www.academia.edu/13165497/Book_Donation_Programmes_for_Africa_Time_for_ a_Reappraisal_Part_I

Part II: Le don de livre, mais à quel prix, et en échange de quoi? Un regard sur le don de livre en Afrique francophone [Book donations, but at what price, and in exchange for what? An overview of book donation practice in francophone Africa] by Raphaël Thierry https://www.academia.edu/13166294/Le_don_de_livre_mais_\%C3\%A0_quel_prix_et_en_ \%C3\%A9change_de_quoi_Book_donation_programmes_for_Africa_part_2 _ (In French, with an abstract in English)

\section{Book prizes and awards}

Umutoni, Louise Establishing a New Literary Prize: The Huza Press Award for Fiction. https://africainwords.com/2016/11/27/establishing-a-new-literary-prize-the-huza-pressaward-for-fiction/ (Posted 27 November 2016) [05/12/16]

Describes the challenges and practicalities of setting up a new literary award in Rwanda, including the appointment of judges and the judging process, the issue of language, financing and sustainability, and the factors that shape a prize's larger impact.

\section{Children's book publishing}

Choi, Nard 'Together We're Strong!': A Review of Book Dash Storybooks. (Posted 13 October 2016) [21/11/16]

https://africainwords.com/2016/10/13/together-were-strong-a-review-of-book-dashstorybooks/

Describes the activities of Cape Town-based Book Dash http://bookdash.org/ that aims to create high-quality, contextually relevant e-books for young readers. Book Dash works by bringing together creative professionals to volunteer to create African storybooks, often through 12-hour book-making marathons called 'Book Dash days'. The storybooks can be freely downloaded, translated, and distributed by anyone through an open licensepublishing model. Book Dash primarily aims to create storybooks for ages 1 to 5 , featuring easy-to-read storylines and incorporating many aspects of South African culture, images, and words. Book Dash provides both print-ready books or digital online versions as PDF ebooks, and thereafter anyone can get print runs sponsored and put finished books into the hands of children. 
Edward, Summer Foreign Correspondence: An Interview with Deborah Ahenkorah: Torchbearer for African Children's Publishing. http://www.hbook.com/2016/11/creating-books/foreign-correspondence-an-interviewwith-deborah-ahenkorah-torchbearer-for-african-childrens-publishing/\#_ (Posted 21 November 2016) [27/12/16]

Deborah Ahenkorah is the co-founder and executive director of Golden Baobab, the panAfrican social enterprise that is behind the Golden Baobab Prizes for African children's literature http://www.goldenbaobab.org/. Based in Accra, it aims to create awareness about the need for more African literature for children, and to draw attention to the still insufficient supply of culturally sensitive books for African children. Golden Baobab's vision, Ahenkorah says, is "to ensure that young Africans have access to books they can relate to and that represent them. It leaves young people feeling empowered and gives them a sense of place in the world." A number of outreach initiatives aim to nurture talented African writers and illustrators through programmes and workshops, and providing creative and technical resources to improve their craft. A sister company, African Bureau for Children's Stories, publishes award-winning African stories for children and supports the careers of children's writers and illustrators in Africa.

Micomyiza, Isaïe Children's Book Industry in Rwanda.

http://akomanet.com/childrens-book-industry-in-rwanda/ (Posted 21 October 2016)

[05/11/2016]

The Rwandan children's book industry has experienced significant growth since the UK charity Save the Children started projects that aim at giving children access to quality books in their mother tongue. There has also been a significant increase in the number of publishing companies dedicated to children literature. More than 20 publishing companies are currently operating in Rwanda. Children's books are a priority for almost all of them, and the Rwandan children's book industry is now also gaining international visibility. The dominating format on Rwandan children's book market is the picture story book, and genres are mainly realistic fiction, fantasy, folktales, historical fiction, and information books. In 2006 Rwanda became the 70th member of IBBY (International Board on Books for Young People), and some international prizes have been won by Rwandan publishers. The Rwandan Children's Book Initiative (RCBI), managed by Save the Children, supported the writing, publication and wide distribution of Kinyarwanda children's books with a focus on Primary 1-3. The ultimate aim of the project is to improve literacy skills and learning outcomes for young children in the first years of primary school by increasing their reading, particularly of high quality and age appropriate books.

Walter, Scott CODE and the Children's Book Project. 25 Years Later - An Enduring Part of Tanzania's Literacy Landscape.

https://www.codecan.org/news/code-and-the-childrens-book-project (Posted 12 October 2016) [30/12/16]

The Children's Book Project for Tanzania http://www.cbp.or.tz/ is celebrating its 25th year of operations. Supported by the Canadian organization CODE, its principal mission is to develop and promote children's literacy, and a vibrant culture of reading and writing, through producing and distributing affordable locally produced books; making quality reading materials available and accessible, empowering teachers with appropriate 
sensitization skills and teaching methodologies, as well as engaging in policy advocacy and promoting stakeholder partnerships. As Scott Walter recalls: "Over time and with much consultation, a plan was crafted that would produce a sustainable supply of relevant, highquality children's books in the Swahili language. Publishing would be recognized as an entrepreneurial activity with the publisher as architect of the book, responsible for a process that starts with research and financing and ends with selling a finished product so the cycle can begin anew. From writers to booksellers, we would support every link in the 'bookchain' to create and sustain an entrepreneurial publishing sector."

\section{Copyright and legal deposit/Authors' rights}

\section{Czerniewicz, Laura Student Practices in Copyright Culture: Accessing Learning \\ Resources. Learning Media and Technology https://www.academia.edu/22304530/STUDENT_PRACTICES_IN_COPYRIGHT_CULTU RE_ACCESSING_LEARNING_RESOURCES [27/06/16]}

The focus of this paper is on South African students' learning resource access practices, particularly those generally considered piracy practices. The paper explores how students report they access learning resources at a research-intensive university in South Africa; whether and how students download and share learning resources (especially books and papers); whether these resources are understood to be legal or illegal; what their attitudes are, as well as the general and practical understandings that enable their access to resources. The author's findings suggest a blurring between the legal and the illegal and indicate the normalcy of piracy practices, with nuanced distinctions and understandings manifest. "The findings of this paper have implications for pedagogy, for student engagement with texts, for plagiarism and attribution and for academic and digital literacies. They also suggest that higher education needs to look closely at the need to change publishing models and entrepreneurial content models so that they are cheaper and easy to use. ... From a variety of perspectives in higher education, it is clear that piracy practices are quite simply part of the new order."

\section{Leguit, Josina Plagiarism, Copyright and Ethical Conduct in Tanzania. Maureen Fondo,} Senior Legal Officer at COSOTA, on Copyright Awareness in Tanzania.

https://www.elsevier.com/connect/video-plagiarism-copyright-and-ethical-conduct-intanzania (Video 3:34mins) (Posted 21 September 2015) [19/12/15]

Understanding and protection of copyright is of great importance in strengthening local publishing in Tanzania, and in this short video the Senior Legal Officer at the Copyright Society of Tanzania http://www.cosota-tz.org/ expresses her concerns about the awareness of copyright in Tanzania. Copyright is one of the issues the Elsevier Foundation's 'Publishers without Borders' two-year programme in Tanzania, and plagiarism and ethical misconduct in Tanzania is a topic that is frequently asked about in their presentations.

\section{Ouma, Marisella "Copyright and Copyright Infringement: The Legal and Institutional} Framework in East Africa." In Coming of Age. Strides in African Publishing. Essays in Honour of Dr. Henry Chakava at 70, Nairobi: East African Educational Publishers, 2016, 256-269.

Discusses copyright law, and the different forms of copyright protection, in the East African region. Infringement of copyright and piracy, the author notes, has become a major problem 
in East Africa, especially in the light of improved Internet speeds, affordable connectivity, and the proliferation of mobiles. For effective copyright protection to be realised, it is important to have an appropriate institutional framework, the author says, and she provides an overview of the work of the different copyright boards and offices active in the countries of East Africa, including the activities of reprographic reproduction rights organizations that collect royalties on behalf of the rights holders. Copyright protection faces many challenges in the region; infringement of copyright and related rights continue to plague the book and creative industries "and needs to be tackled from a policy and practical perspective" the author says, in order to create a sound policy framework both at the national and regional level. It is also crucial, Ouma argues, to embrace technology "and look for ways in which we can have the balance between the rights of the author and access by users without prejudicing the interests of the rights holder." Moreover, education and awareness creation are necessary, "and should start at an early age so that people can grow to appreciate copyright and related rights as an important aspect of our daily lives and a major contributor to the economy."

Röschenthaler, Ute and Mamadou Diawara, eds. Copyright Africa. How Intellectual Property, Media and Markets Transform Immaterial Cultural Goods.

Canon Pyon (Herts, UK): Sean Kingston Publishing, 2016. 408 pp.

This volume is a significant contribution to a frequently misunderstood field: the study of intellectual property regimes in 'the real world', and the historical development of intellectual property rights in Africa and their local realizations in what is now an increasingly mobile and globalized world. The volume brings together detailed ethnographically and historically informed studies of a wide range of contexts of immaterial culture in sub-Saharan Africa, showing how (post)colonialism, commercialization, new technologies and new legal frameworks, amongst other factors, have affected them. Drawing on case studies from Cameroon, Kenya, Nigeria, Mali, Senegal and South Africa from an interdisciplinary team of legal experts, anthropologists and literary scholars - these investigations aim to demonstrate how local actors use IP and how international property legislation actually plays out on the ground; and "what happens to intangible cultural goods when they are confronted with large-scale commodification and distribution through media technologies, and defined by globalized and divergent judicial systems, institutions and cultural norms." The studies open up a complex picture of the intricate interconnections among pirates, artists, communities, governments and international organizations. As the editors argue, "it is only when local actors embrace technologies and regulations in a specific historical situation that these become influential forces for change. The question raised is not whether international IP norms conform to African practices, nor whether media impose a Western style, but rather what local actors do with these regulations, and how both local and Western practices and technologies impact on each other and co-exist."

\section{Digital media and electronic publishing}

Attwell, Arthur Three Things Every Editor Should Know about Digital Publishing. http://arthurattwell.com/2016/01/03/three-things-every-editor-should-know-about-digitalpublishing/ (Posted 03 January 2016) [16/04/16] 
“Today, every passage you edit will sooner or later be read on screen. This digital world desperately needs our craft and high standards, but what does that mean for our daily work" asks Arthur Attwell. He picks out what he see as the three most important developments in digital publishing/editing - text-only editing, collaborative editing, and automagical pagination - and describes some of the tools that can be used to tackle them. Based on a talk given at the Cape Town Professional Editors Group.

Brown, Ashleigh, et al Learning from the Children's Books and E-learning Pilot Project with Kenya National Library Service 2013-2015. London: Book Aid International (Book Aid International Learning Paper), 2016. 28 pp.

http://www.bookaid.org/wp-content/uploads/2016/08/Book-Aid-International-Childrenbooks-and-digital-learning-paper-FINAL.pdf [15/12/16]

Supported, among others, by the Stavros Niarchos Foundation, The Children's Books and Elearning Project 1 is a joint project by Book Aid International and the Kenya National Library Service. The project focused on 23 public libraries, training librarians on working with children, developing new Children's Corners that provided dedicated areas for children in 10 libraries, working with 12 public libraries that had established Children's Corners, and providing them with top-up books. In five of these public libraries, children were given access to e-readers and tablet computers, using them to develop reading, research and basic ICT skills. Some of the main challenges reported during this project include unreliable Internet connections, a lack of varied religious texts to suit the religious diversity of some areas, the need for more hardware to satisfy the numbers wanting access, and problems with procurement of tablet covers. The authors report that, despite these challenges, the response to the project has been overwhelmingly positive.

In their conclusion the authors state: "Ultimately, this project has demonstrated that UK donated books, locally purchased books and content provided on e-readers and tablets all have intrinsic value to libraries and the communities that use them. Children enjoy using their refurbished spaces and are enthusiastic about their new resources, which has led to an increase in library attendance. Their new digital resources have helped them to learn through apps and games, as well as attracting a wider range of users into the library which has helped to build community. Librarians now have greater understanding of children's needs and are therefore more motivated."

Copyright Clearance Centre. Beyond the Book Worldreader Brings Digital Library to Africa.

http://beyondthebookcast.com/worldreader-brings-digital-library-to-africa/ (Podcast, 12:04mins. [27/12/16]

Worldreader https://www.worldreader.org/ with headquarters in San Francisco, and offices in Barcelona, London, and Accra, has since 2010 assembled a digital library some 46,000 books in 43 languages, with the goal to reach "every child and her family so that they can improve their lives", and the arrival of digital devices (a wide choice of e-books preloaded on donated e-readers) is helping to bring books and digital reading to even quite remote communities in Africa. This is a podcast interview with Danielle Zacarias, Director, Content \& Publisher Relations at Worldreader, in which she talks about the activities of Worldreader in a number of African countries, their work and collaboration with African publishers, the nature of the books that are currently available, the readers or groups of people that are 
benefitting from this initiative, the most successful titles thus far, and their biggest success stories to date. (For more information, stories, and background about current Worldreader activities in Africa, and the top books in 2016, see also their blog 'The Literacy Ledger' at https://www.worldreader.org/blog/.)

\section{Elusoji, Solomon Random Thoughts on the Economics of Internet Publishing. http://www.praxismagonline.com/random-thoughts-on-the-economics-of-internet- publishing/ (Posted 24 May 2016) [01/06/16]}

"Nigerian book publishers need to do more in the digital space, as a revolution is about to happen", the author proclaims. Publishers in Nigeria are reluctant to make their books available in digital formats because they fear content will be pirated. But publishers are short-sighted, he says, and "have been the most conservative and sceptical" of the Internet's potential, the new digital environment, and e-book platforms. He concedes, however, "the big question that should bother anybody who reads books in Nigeria is this: how do you reconcile the Internet's free model with the need to pay authors and publishers enough money, the need to incentivise the creators of books to create more books?" Although the author believes that "commercial print books will stick around, at least to the middle of this century", digital books will gain more ground. "And no one should be scared - not in Nigeria anyway. We do not have the gargantuan print-focused publishing infrastructure of Europe and North America, so we have a better chance of creating the publishing space of the future. Our past is weak, and we have fewer debts to settle." Solomon Elusoji is cofounder at Wanmilion http://www.wanmilion.com/, a start-up seeking creative ways to get more people to read more books.

Gaigher, Susan; Elizabeth le Roux, and Theo Bothma The Effect of Digital Publishing on the Traditional Publishing Environment Innovate 9 (2014): 95-101. http://www.up.ac.za/media/shared/404/ZP_Files/Innovate\%2009/Articles/the-effect-ofdigital-publishing.zp40045.pdf [16/04/16]

Digital technologies, such as e-books, are predicted to have a profound effect on publishing, but are yet to have a serious impact on the South African book industry [as at 2014]. Research conducted in the Department of Information Science at the University of Pretoria considered the implications of digitisation and digital publishing for the trade book publishing industry in South Africa by evaluating the current state of the industry using the context and predictive value of disruptive technology theory. The authors note that as long as digital publishing remains a niche market, the costs involved do not justify overturning publishers' existing business models entirely, and the technical costs of setting up a digital publishing system might currently outweigh the potential sales of e-books. Moreover, a traditional publishing company's change to an electronic publisher demands a huge reorganisation effort and a great deal of investment: "Publishers are only likely to invest enthusiastically in e-books once the market grows to a significant size and scope. However, disruptive technology theory provides us with many cautionary tales of businesses that did not invest in new technology for these very reasons. When the tipping point is reached and the digital publishing market becomes profitable, traditional publishers that did not invest in digital technologies will face the risk of being left behind. The recommendations formulated from disruptive technology theory can provide a useful 'how-to' guide for publishers implementing and managing digital publishing in their business processes." 
Kwauk, Christina, and Jenny Perlman Robinson Worldreader Creating a Culture of eReading Around the Globe. Washington, DC: Brookings Institution, Centre for Universal Education, 2016. 27 pp.

https://www.brookings.edu/wp-content/uploads/2016/07/FINAL-Worldreader-CaseStudy-1.pdf

An appraisal of Worldreader's https://www.worldreader.org/ digital reading programme (2010-present), which aims to provide school children and their families in 53 countries with access to culturally and linguistically relevant digital books, by supplying schools (e.g. through its iREAD programme in Ghana) and libraries (e.g. through its LEAP programme in Kenya) with low-cost e-readers and tablets that are loaded with digital books and other digital teaching and learning materials. Worldreader aims to improve literacy skills by helping to create a culture of reading in places with very limited access to reading materials. Outside school contexts, the organization has also developed Worldreader Mobile, a suite of free mobile reading apps with access to its digital library content, which are built for a variety of platforms, from Android to mobile web browsers. Worldreader seeks to pursue an integrated approach that combines context-appropriate technology, digital access to over 37,000 book titles in 43 languages, together with teacher and librarian support, and community engagement. This Brookings Institution study provides further background about Worldreader's operation and activities, costs and operating budgets, reviewing its impact and evidence of success, the key drivers behind scaling impact, planning for longterm financial sustainability, and "Lessons learned".

\section{McNulty, Niall The Changing Role of the Publisher in the Age of Plenty.} https://creativecommons.org/2016/08/03/changing-role-publisher-age-plenty/ (Posted 03 August 2016) [26/08/16]

Niall McNulty is currently digital publishing manager at the African branch of Cambridge University Press in Cape Town http://www.cup.co.za/. In this interesting blog posting he sets out his thoughts how a traditional publishing business could engage with the open movement and the plethora of freely-available content online. McNulty says "Sub-Saharan Africa has a vibrant and diverse publishing industry, with local and international players producing content in a number of languages across various genres. Due to market conditions, however, many print books need to be sold at low-price points, e.g. full-colour, senior level textbooks are sold for less than $\$ 3$ in some countries. At the same time governments and NGOs are constantly looking for ways to make content freely available as budgets for learning and teaching resource material are squeezed." So what, then, are the opportunities and challenge for publishers when content is freely available in the new digital environment? How can a conventional commercial publisher engage with and use open resources, how does this sit alongside copyrighted content, and what other revenue streams or business models can a publisher embrace to develop sustainable businesses? McNulty then describes two existing projects, as well as outlining his thinking about a few other potential business models. In his conclusion he states "While still in the early phases of my thinking and experimentation around open business models and the relationship to education and publishing, it does seem that opportunities exist to explore new revenue streams that can embrace and re-use open content while at the same time providing sound pedagogic solutions to learners in sub-Saharan Africa that are innovative and of a highstandard." 


\section{Njau, Barbara We Do Everything Online So Why Aren't We All Reading E-Books?}

https://trueafrica.co/lists/we-do-everything-online-so-why-are-people-still-reluctant-toread-e-books/ (Posted 30 June 2016) [06/07/16]

Barbara Njau of digital publisher Bahati Books http://bahatibooks.com/ makes a strong pitch for the virtues of the e-book, e-readers and tablets. "Why baulk at the inevitable. Why challenge change instead of embracing it?" she asks. When you go on holiday you need space in your suitcase for more clothes and shoes, rather than "heavy novels". Pity the poor students travelling to and from class with several books in their bags; and no trees need to be chopped down to produce books, she argues. Moreover, "the gatekeepers are gone thanks to e-books", and "costly, hardcopy publishing has been shunned by nimble publishers", she asserts. While not everyone will agree with this claim, she makes some entirely valid points, especially as it relates to books and reading in Africa, and the cost and availability of conventional books. It is also true that reading on e-readers, tablets and low-end mobile apps offer genuinely exciting opportunities to promote books and reading to a much wider audience than was hitherto possible, recruiting new readers, and helping to get more content to more people at a price they can afford.

\section{Ry-Kottoh, Lucy “Will Access to E-Books Improve Literacy in Ghana?” Common Knowledge (June 2016): 8-9.}

http://cscuk.dfid.gov.uk/wp-content/uploads/2015/11/common-knowledge-issue-2.pdf [26/10/16]

Lucy Ry-Kottoh, currently completing her PhD at the University of Stirling in Scotland, reports some of the preliminary findings from her ongoing research project that examines digital children's book publishing in Ghana. This research aims to investigate the level of adoption of digital book publishing technologies among Ghana's publishers, and looks at the factors that influence them to adopt or not to adopt e-book technology. The particular focus is on children's publications, to ascertain the role that e-books can and should play in supporting teaching and learning. Based on an examination of the infrastructure that supports a vibrant e-book industry, the study will also assess the skill levels of those working in the Ghanaian publishing industry. This in turn will inform the design and structure of training programmes in those areas of e-book publishing where capability is lacking at this time.

\section{She Leads Africa Nneka Offor: Digital Publishing Can Transform Learning in Africa.} http://sheleadsafrica.org/nneka-offoro-whiteleaf-digital/ [24/07/16]

Nneka Offor is the founder and CEO of WhiteLeaf Digital http://www.whiteleafdigital.com/, a digital publishing company based in Enugu, Nigeria. In this interview she sets out her views how the digital revolution will affect reading and learning, the prospects for e-books and e-learning in Nigeria, and how she believes digital publishing will transform the African educational sector.

Shehu, Mohammed, and Nobert Jere e-Reader Deployment in Namibia: Fantasy or Reality? In Proceedings of the International Congress on Information and Communication Technology, ICICT 2015, vol. 1, edited by Suresh Chandra Satapathy, Y.C. Bhatt, A. Joshi, and D.K Mishra. Berlin: Springer International Publishing, 2016, 627-635.

http://link.springer.com/chapter/10.1007/978-981-10-0767-5_65 (subscription based, pay per view) [24/07/16] 
As technology grows and the usage of ICTs becomes popular all over the world, modern approaches are required to improve service delivery through technology. The education sector has been a beneficiary of such approaches. In some cases, however, determining the best technologies to implement has proven a much more complex endeavour. In this paper, an evaluation of the possible impacts of e-reader implementation in Namibian schools was undertaken, with several stakeholders within the Namibian education sector engaged and their feedback recorded and analysed. The author's findings show that several infrastructural and social issues still need to be addressed before the application of innovative solutions to existing challenges, such as for example e-reader deployment in schools, can succeed. [Abstract, not examined]

\section{Smart Monkey TV Kudakwashe Kamupira and Barbara Njau, Bahati Books on E- Publishing in Africa. https://www.youtube.com/watch?v=51S0CqER8_k (Published 30 May 2016) (Video 6.51mins ) [24/07/16]}

An interview with Kudakwashe Kamupira and Barbara Njau, co-founders of of Bahati Books http://www.bahatibooks.com/, an e-book publishing company "that aims to bring to global readers captivating and well-written African literature by African authors". They talk about their motivation for setting up the new venture, their mission and publishing ecosystem, the authors they have published to date, and also discuss the state of epublishing on the continent, its challenges, and the prospects ahead. At a continental level, Bahati is putting its books on the Nigerian e-publishing app Okadabooks http://www.okadabooks.com/, which claims to have 175,000 users worldwide.

Trucano, Michael Digital Teaching and Learning Resources: An EduTech Reader. http://blogs.worldbank.org/edutech/dlr-reader (Posted 23 February 2016) [15/04/16]

A useful inventory of quite a substantial number of posts related to the use of digital teaching and learning materials in Africa and elsewhere that have appeared on the World Bank's EduTech blog https://blogs.worldbank.org/edutech/, and which are brought together here with links to all the posts/articles. Some additional information about the World Bank's work related to textbooks in Africa can also be found on these pages.

\section{Educational and school book publishing}

\section{Abrams, Dennis 'A Single Schoolbook for Each Subject': Mozambique's New Approach http://publishingperspectives.com/2016/09/mozambique-textbooks/\#.V8qsjPkrJD9 (Posted 01 September 2016) [06/09/16]}

Reports about the decision by the Mozambican Ministry of Education that, as from the 2017 school year, it will only adopt a single book for each subject taught in the country's secondary schools, thus ending the current situation of a multiplicity of books, from a variety of publishing houses, chosen by each of the schools. The measure, according to a government spokesman, "is intended to reduce the prices of secondary school text books", also noting that "there is a great lack of school books among secondary pupils, due to their weak purchasing power". In a 'Comments' posting in this Publishing Perspectives article the International Publishers Association http://www.internationalpublishers.org/ expresses its concern about this development: "In our experience, the best performing education systems 
encourage educational publishers to compete in an open market, producing innovative solutions that meet local needs. By stark contrast, what is about to be implemented in Mozambique, [according to the report] is a recipe for a steep decline in the quality and range of available educational resources in that country, as publishers stop investing in the local market. This can only result in disastrous educational outcomes for students in government schools and a widening gulf between the education they receive and what those students in private schools can get. The latter will benefit from the rich range and depth on offer from the best educational publishers, both locally and internationally. We urge the government of Mozambique to reconsider and deliver the best possible educational material available, rather than make a short-sighted decision that is obviously aimed at reducing education spending in the short term, but will do irreparable harm to the country in the long run."

\section{Abrams, Dennis Tanzania's Ban on Privately Published Textbooks Triggers Controversy. http://publishingperspectives.com/2016/12/tanzania-bans-private-textbook-publishing/ (Posted 08 December 2016) [15/12/16]}

According to reports in Tanzanian newspapers, Prime Minister Kassim Majaliwa has reportedly banned private companies from publishing textbooks, as one of the measures to ensure provision of quality education in the country. "Our aim is to ensure there are specific books for specific subjects and each student must use his/her own book during class sessions," he said. The Prime Minister stated that some people have been publishing textbooks without adhering to requisite standards, leading to complaints of poor quality and errors. Speaking at a meeting of Arusha City Council's teachers, he is reported to have said that the government has instructed the Tanzania Education Authority (TEA) to henceforth "supervise the publishing" of all textbooks. The controversial decision has apparently come as a shock and as a complete surprise to Tanzania's book publishers. The Executive Secretary of the Publishers Association of Tanzania, Benito Mtulo, has expressed concern about the government's decision, which was apparently made without consultation with the members of the book industries. Some reactions by local publishers, as well as section of education stakeholders - while acknowledging that quality is seriously wanting in some available textbooks - would indicate that there is considerable apprehension that the directive will seek to eliminate all private sector publishing in the educational field.

Federal Democratic Republic of Ethiopia. Ministry of Education Early Grade Reading Interventions in Ethiopia: Developing Quality Books and Ensuring Access. http://www.saide.org.za/resources/newsletters/Vol_22_no.4_2016/Content/Ayalew_Ethiopi a.pdf

A PowerPoint presentation and analysis describing early grade reading interventions and projects in Ethiopia and its achievements, which has included the development of high quality reading and learning materials in seven Ethiopian languages. The presentation sets out the processes used to create the products and teachers' guides, and aspects such as capacity building, quality control, pilot testing procedures, validation and post validation processes, getting the learning materials into the hands of students and teachers, and collaboration with partners to develop high quality SRMs. A final section includes an overview and assessment of the results to date, and teachers' and students' reflections on the new books that have been created. 
International Publishers Association Public Education in Mozambique to Suffer Under

New 'Closed Market' Textbook Policy.

http://www.internationalpublishers.org/educational-publishing/education-publishingnews/432-public-education-in-mozambique-to-suffer-under-new-closed-market-textbookpolicy (Posted 29 September 2016) [03/10/16]

Public educational performance in Mozambique is likely to plunge when a change in textbook policy takes hold, the International Publishers Association (IPA) has warned the country's education minister, who has announced that all secondary school pupils will only have access to one book per subject per year from 2017. Announcing the policy, Mozambique's Education Minister Jorge Ferrão, said the measure was designed to lower the cost for secondary school textbooks, and that books currently in circulation would continue to be used, albeit for "complementary consultation". He claimed that the policy of adopting one officially sanctioned textbook per subject will improve issues of accessibility and provide Mozambican pupils with "a longer and more complete education". The IPA has written to Minister Ferrão to urge his government to reconsider the move, which stands to drive down the quality of educational resources and, consequently, educational performance in public schools. The IPA's Educational Publishers Forum, which represents the major educational publishers associations around the world, "strongly believes that the best performing education systems encourage educational publishers to compete in an open market, producing innovative solutions to meet local needs."

Matinde, Vincent Kenya: Integrating e-Books in Education.

http://www.idgconnect.com/abstract/14675/kenya-integrating-books-education (Posted 01 April 2016) [12/06/16]

Citing the late Tony Read's World Bank study Where Have All the Textbooks Gone http://documents.worldbank.org/curated/en/883821468179671004/pdf/97932-PUB-

Box391498B-PUBLIC.pdf (see separate record below) some policy makers in sub-Saharan Africa see e-materials as potential replacements for printed textbooks and reading books. The Kenyan government has now launched a digital content page for e-learning. The site, KICD Interactive Content http://kicdinteractivecontent.ac.ke/ will allow publishers to upload their e-books to be used across the board. A number of Kenyan publishers are reportedly warming up to this new and perhaps inevitable change in content demand, and believe the move by the government is a step in the right direction in as far as it provides a structure within which digital content can be made available to schools. Several local publishers have their content already available in PDF and most have converted some of this content into ePUB format, in view of its versatility when viewing on a wide range of mobile devices. However, while publishers may well be attracted by digital publishing for schools, Mary Maina, General Manager of Moran Publishers in Kenya http://moranpublishers.com/ - who already offer 200 titles in digital book formats - cautions that it is easy to be excited about a technology without evaluating the environment in which it is used. And, as emphasized in the Read study, there are many challenges, notably the considerable costs of developing digital content, cost implications of hardware and software procurement, maintenance and replacement; and overall development of e-learning has to be coupled with other developments relating to infrastructure and Internet provision. 
McCallum, Kate More Damage Predicted for Educational Outcomes: The Case Against Approving Only One Textbook.

http://www.praesa.org.za/wp-content/uploads/2016/09/PRAESAMoreDamage-1.pdf [15/12/16]

A recent proposal by South Africa's Department of Basic Education is to do away with the national catalogue of eight textbook books per subject per grade, and to approve only one book, which is predicted to damage further South Africa's already poor educational outcomes. Kate McCallum (a former Chair of the Publishers Association of South Africa) here makes a convincing case that the proposal to remove all choice of books by schools from a national catalogue of eight approved titles, and to have only a single approved textbook is a retrogressive step, and is likely to damage an already fragile educational system. She says that unlike many other countries, South Africa's teaching corps is exceptionally diverse in its background, teaching ability, language ability, and content knowledge, and that a single book will not address all these differing needs. "An education system in an open, free, fair, non-racist and democratic society must offer a diversity of materials to all learners. There is no rainbow with only one colour. A national catalogue with diversity of content, methodology and approach offers diversity and fosters innovation and creativity." A competitive publishing environment drives quality up and prices down, whereas a single option catalogue will create monopolies, which ultimately are not likely to be cost-effective, and "it is also obvious that a single-book choice system is a winner-takesall system, which increases the risk of corruption."

Ojeniyi, Ayo "The Dominance of the Textbook in African Publishing." In Coming of Age. Strides in African Publishing. Essays in Honour of Dr. Henry Chakava at 70, Nairobi: East African Educational Publishers, 2016, 70-94.

Nigerian publisher Ayo Ojeniyi provides a synopsis of the development of educational and school book publishing on the continent, with broad overviews of the situation in a number of countries in West, East, and Southern Africa, and describing the challenges, and the vagaries, of textbook publishing both for schools and tertiary education. The size of the textbook market can be huge in some countries like Nigeria or Kenya, and can amount to over $90 \%$ of total revenue of the book industries. Many African countries share similar experiences in the textbook sector, and most of the problems associated with textbook publishing remain largely the same today as they were two decades or more ago: among them the lack of national book policies, inconsistent educational and fiscal policies, and frequently changing curriculum and teaching syllabuses (leaving publishers stuck with obsolete books), as well as slow payment to publishers for books supplied to schools or through government agencies. A weak retail sector and a poor distribution network is another serious handicap, and "is perhaps the weakest link in the book chain in Africa today."

Among other problems the author cites is a fragile local printing infrastructure that is frequently unable to cope with rapid technological advances in the printing industries, together with high import tariffs on raw materials required for printing and binding including paper and boards. A relatively new, but now very serious menace is piracy, coupled with inadequate enforcement of copyright laws in most African countries. While state control of school book publishing is now largely a thing of the past, a new threat to textbook publishers are moves by some governments - for example in Tanzania recently, or 
in South Africa currently - to replace a choice of several textbooks for each subject with just one book per subject and per class. Despite this litany of problems, and by virtue of the massive expansion in education in Africa, Ojeniyi feels optimistic about the future. He predicts that "the publishing business generally and textbook publishing in Africa more specifically have bright prospects", but warns that publishers in Africa currently lack the capacity to meet the textbook demands; it is therefore essential to enhance capacity and that this requires an enabling environment for books and other learning materials to be made available in the right quantity, quality, and variety.

Opoku-Amankwa, Kwasi; Dora F. Edu-Buandoh, and Aba Brew-Hammond "Publishing for Mother Tongue-Based Bilingual Education in Ghana: Politics and Consequences."

Language and Education, 29, no. 1 (2015): 1-14

http://www.tandfonline.com/doi/pdf/10.1080/09500782.2014.921194 (subscription based/pay

per view) [16/02/16]

Also at (freely accessible)

https://www.researchgate.net/publication/269286616_Publishing_for_mother_tongue-

based_bilingual_education_in_Ghana_politics_and_consequences [09/08/16]

One often cited challenge to effective mother tongue-based bilingual education (MTBE) in multilingual countries like Ghana is the difficulty of developing curriculum and instructional materials in many languages. To explain this situation, factors such as shortage of writers and teachers in the local languages, lack of interest on the part of publishers in view of the wide availability of textbooks in multiple languages, as well as official support for dominant western languages, such as English, are usually cited. This paper discusses the veracity of these claims, by examining pre- and post-independent governments' efforts at material development to support MTBE in Ghana. The authors point out that, while most educational policies and reforms in pre- and post-independent Ghana have emphasised the importance of mother tongue education, there has in fact been no concerted attempt to design and implement a language-in-education policy that incorporates the urgent need to develop curriculum materials for MTBE. This is attributed primarily to a lack of political will, exhibited in the limited support in terms of resources offered for the development of Ghana's languages by successive governments, as well as fuelled by myths and misconceptions about mother-tongue education: "The fact remains", the authors state, "that the use of an unfamiliar language as a medium of instruction denies full access to education for the majority of children from socio-economically disadvantaged families."

Opoku-Amankwa, Kwasi; Aba Brew-Hammond, and Anatu Kande Mahama Publishing for Pre-tertiary Education in Ghana: The 2002 Textbook Policy in Retrospect.

Educational Studies 41, no. 4 (2015): 414-429.

http://www.tandfonline.com/doi/full/10.1080/03055698.2015.1018873 (subscription

based/pay per view) [16/02/16] [20/06/16]

Assesses the performance of the Ghanaian government's 'National Textbook Development and Distribution Policy for Pre-Tertiary Education' of 2002. It examines the policy in theory and in practice by exploring the extent to which the liberalisation of the textbook sector has helped to improve on textbook procurement, production and distribution, availability, quality and access to the books. The paper discusses the context leading to the transition from the state-controlled policies to the present liberalised textbook provision policies. The tensions that marked the transition period, and the role of the World Bank and other 
development agencies in the policy shift, are also discussed. The authors identify a number of implementation challenges that prevented the full realisation of the objectives of the textbook policy, including the Ministry of Education's interference in the textbook procurement process, and some publishers' and authors' abuse of the conflict of interest regulation in the policy. The paper concludes with a range of recommendations for consideration.

\section{Read, Tony Where Have All the Textbooks Gone? Toward Sustainable Provision of} Teaching and Learning Materials in Sub-Saharan Africa. Washington, DC: International Bank for Reconstruction and Development/The World Bank, 2015. 295 pp.

Online (freely accessible):

\section{http://www-}

wds.worldbank.org/external/default/WDSContentServer/WDSP/IB/2015/07/08/090224b082 fdf234/1_0/Rendered/PDF/Where0have0all0n0Sub0Saharan0Africa.pdf [02/02/16]

Supported by a wide array of statistical analysis, this comprehensive World Bank study examines a multiplicity of issues surrounding the complexity of textbook provision in SubSaharan Africa, and the cost and financing barriers to universal textbook provision in the region. These include education issues - including curriculum development and review, teaching and learning materials (TLM) provision, language of instruction policies - as well authorship and publishing, bidding processes and procurement systems, distribution and storage challenges, manufacturing and cost issues, materials development and design, and more.

Recent issues raised by various attempts to embed information and communications technology (ICT) and other educational technologies within national education systems are examined in Chapter 12, "The Potential Impact of Information and Communication Technology Solutions on Textbook Provision", which discuss e-alternatives to textbook provision, e-readers, and the use mobile or smart phone-based learning materials, and also includes a useful summary of emerging issues in this area. The author sets out some of the many fundamental questions that education systems need to address before they decide how much ICT do they want, or need to have for their education system. "It is not necessarily possible to resolve these issues prior to major investments in ICT, but at the very least these issues and questions should form an important part of the thinking that should underpin the development of national strategies. This is not happening in very many, if any, SSA countries, but until these issues are addressed and resolved it should not be assumed that ICTs will yet provide an affordable, sustainable, or effective - and certainly not a cheaper - alternative to print-based teaching and learning materials."

The final Chapter 13, "Options in the Development of National Teaching and Learning Materials Policies", looks at the issues of private sector vs. parastatal textbook producers, centralization vs. decentralization, language policies and literacy, monopoly vs. competitive supply, cost-reduction strategies, and presents country comparisons of five key textbook issues in ten countries, and as it relates to authorship and publishing, procurement, printing, financing, and distribution. Textbook system design, the author states, is a specialized activity requiring good research and an appreciation of the various factors that impact on affordability. "Poor distribution has been perhaps one of the major factors over the past 50 years, combined with poor usage, management, and conservation in schools; but different 
countries will have different strengths and weaknesses and while the basic principles can be specified, the unique system problems and solutions have to be resolved on the basis of the circumstances and needs of individual countries."

Results for Development Institute (R4D) and International Education Partners Ltd. (IEP)

Global Book Fund Feasibility Study. Final Report April 2016. Washington, DC: Results for Development Institute 2016. 362 pp.

http://www.r4d.org/sites/resultsfordevelopment.org/files/resources/Global\%20Book\%20F

und \%20Feasibility\%20Study\%202\%20pager_\%20final.pdf (2 page summary)

http://www.r4d.org/sites/resultsfordevelopment.org/files/resources/R4D-

IEP_GBF_ExecSummary_web.pdf (Executive summary 20 pp.)

http://www.r4d.org/sites/resultsfordevelopment.org/files/resources/R4D-

IEP_GBF_Full\%20Report_\%20web.pdf (Full report 362 pp.) [15/12/16]

also at

http://pdf.usaid.gov/pdf_docs/PA00M8BK.pdf

The Global Book Fund (now renamed Books for Every Child: The Global Book Alliance/GBA) is a major new initiative involving a wide range of partners that is building on the experience from health sector commodity reform to transform the development, procurement and distribution of books for the education sector. Its principal objective is increase book quality and availability in low income countries, while decreasing costs. The initial focus will be on books for reading instruction and practice in mother tongue languages, including African languages. In its background statement and Executive Summary the GBA says:

"Although there have been major strides in education enrolment over the past 15 years, 250 million children of primary school age are still unable to recognize basic letters and numbers. Worryingly, 130 million of these children attend 4 years or more of school and still leave without basic foundational skills. Evidence supports the role of books in improving learning and reading acquisition, yet many children lack access to both reading books and textbooks. Over the past few decades, donors, including bilateral organizations and private foundations, have provided millions of dollars in funding and programmatic support to improve book provision and usage. Despite this extensive support, there continues to be an underfinancing of books, and the problem persists."

The Global Book Alliance says it will be a transformative international mechanism to mobilize funding, raise awareness, and improve the provision and use of both textbooks and reading books. Its proposed key activities are set out in this report, which include:

(i) Becoming the go-to one-stop shop for knowledge and best practices on the effective development, procurement, distribution, and usage of all books. Advocating and instilling the importance of reading materials.

(ii) Bringing donors and diverse stakeholders together to coordinate around book chain issues and to foster long-term policy dialogue.

(iii) Helping countries make their book chains more efficient through finance, technical advice, and joint learning, in order that books actually reach students at reasonable cost and are then used by teachers and students; and 
(iv) where needed, funding reading books in mother tongue languages that correspond to languages of instruction where there is a demonstrated financial need and country commitment.

UNESCO. Global Education Monitoring Report. Every Child Should have a Textbook. Paris: Global Education Monitoring Project, UNESCO (Policy paper 23), 2016. 13 pp. http://unesdoc.unesco.org/images/0024/002433/243321E.pdf [15/06/16]

The amount a country spends on learning materials is a good indicator of its commitment to providing quality education for all. Textbooks are recognized as core for the new Sustainable Development Goals on education, and are especially relevant to improving learning outcomes in low income countries with large class sizes, a high proportion of unqualified teachers, and a shortage of instructional time. Yet, as this paper demonstrates, in many countries students at all levels either lack books altogether or are required to share them extensively with others. The cost of textbooks is a key barrier that prevents children from having access to the learning materials they need. This study investigates the cost of textbooks and the miniscule budget currently allocated to textbooks by many developing countries, including those in sub-Saharan Africa. It considers how the innovative finance model used by Gavi, the Vaccine Alliance http://www.gavi.org/, could encourage private sector investment in the textbook sector. "New GEM Report analysis shows how following this model could take US $\$ 3$ off the price of each textbook, saving almost a billion dollars from the cost of textbooks in sub-Saharan Africa alone, and tripling the number of textbooks available to children around the world." The report concludes with a number of recommendations how, by adopting the Gavi business model, this could be achieved.

Journals and magazine publishing (see also $\rightarrow$ Open access publishing and licensing, $\rightarrow$ Scholarly publishing)

Gray, Eve/OpenUCT Initiative Project An Elsevier African Megajournal Proposal Recolonizing the University in Africa?

http://openuct.uct.ac.za/elsevier-african-megajournal-proposal-re-colonizing-universityafrica (no posting date) [15/07/16]

Another version also at http://www.gray-area.co.za/2016/06/23/an-elsevier-africanmegajournal-proposal-re-colonizing-the-university-in-africa/ (Posted 23 June 2016)

The major international publishing giant Elsevier has recently announced a proposal to explore the potential for the development of an African "Megajournal" (and see also http://www.scidev.net/global/publishing/news/elsevier-african-open-access-journal.html). Partnering with the African Academy of Sciences, the African Centre for Technology Studies, the South African Medical Research Council, and IBM Research-Africa, it is a project that seeks to improve visibility, discoverability and accessibility of African research. While this will probably be welcomed by many, this provocative blog posting by Eve Gray raises some very pertinent questions: "Could this mean that Africa - which until recently has hardly been on the radar of the big international journal publishers - has something to offer this large and hard-nosed multinational academic journal publisher? Could this venture under the Elsevier banner provide the impact act and prestige that the continent's research has been so sadly lacking? Or could it be simply that it could provide a blank slate for Elsevier, experimenting in the face of market uncertainty? Or, at its crudest, just a neo- 
colonial land-grab in the face of challenges in the markets that Elsevier dominates?" Gray goes on to say, "it is perhaps a sad commentary on perceptions of the African continent that when a big corporation targets Africa as a new market, as Elsevier appears to be doing with this proposal, one of the first questions that can be asked is, 'Does this mean that Elsevier's business model is under threat?' Given that the European Union, for example, is aiming for mandating full Open access to research by 2020 with no embargoes, and affordably - and given also that governments like the Dutch government have been engaged at national level in hard negotiations with Elsevier to reduce subscription costs at a national level, it is quite possible that the commercial publishers are indeed worrying about the future of their current very high profit business model." There are also serious questions to be asked, Gray says, about what it will mean for African governments to have this scale of strategic research publication (scientific, medical, technological and research networking) "placed in the hands of a profit oriented publisher as hard-nosed as Elsevier." Moreover, while it could be argued that OA status would protect the journal and its content from capture, "there is surely a risk in allowing a commercial company, and one with a very strong commitment to high profit levels and to the exclusionary competitive ethos of the Impact factor, to have control of the research publications of key African research councils. The research produced by these councils is of national and regional importance and its capture by a commercial company might put at risk the ability to leverage the research for public benefit."

\section{Nyamweru, Celia Africa-based Scholars in Academic Publishing: Q\&A with Celia \\ Nyamweru.}

http://blog.oup.com/2016/09/african-scholars-publishing-celia-nyamweru/ (Posted 09 September 2016) [12/09/16]

In an effort to address current discussions regarding Africa-based scholars in academic publishing, the editors of African Affairs http://afraf.oxfordjournals.org/ reached out to Celia Nyamweru for input from her personal experiences, and as a former Academic Dean at Kenyatta University in Kenya where she worked for 19 years. Some of the questions posed include: How do the daily pressures and tasks required of professors in African universities affect their ability to research, write, and publish in high ranking journals? What are the challenges that African-based scholars face in publishing articles with highly ranked African studies journals? And what can and should be done to support African-based scholars in publishing in top-ranked journals?

\section{South African History Online Staffrider Magazine (1978-1993).}

http://www.sahistory.org.za/article/staffrider-magazine-1978-1993 (last updated 20

September 2016) [14/12/16]

Staffrider was a significant South African literary and cultural magazine published by Ravan Press in Johannesburg from 1978 to 1993. Works by well-known South Africans were featured alongside previously unpublished authors and artists. The magazine provided a valuable publishing platform for aspiring writers, artists, photographers and community projects and offered a forum to challenge racial and cultural oppression. Staffrider's editorial policy was based on an anti-apartheid ethos. To this end Staffrider was non-racial, populist and chose English as its language of publication rather than Afrikaans. These pages provide a short history of the magazine, as well as access to an archive of digitized versions of 37 back issues at http://www.sahistory.org.za/collection/32406. 
Wasserman, Herman, and Ian Richards "On the Factory Floor of the Knowledge

Production Plant: Editors' Perspectives on Publishing in Academic Journals."

Critical Arts. South-North Cultural and Media Studies 29, no. 6 (2015):725-745.

http://dx.doi.org/10.1080/02560046.2015.1151109 (subscription based/pay per view)

[10/08/16]

Debates about the asymmetries in global scholarly production have highlighted the problems that hound African scholarship, ranging from the political economy of publishing to epistemological bias among peer reviewers. Surprisingly little research has, however, been devoted to the views of the journal editors who play such a central role in the process of dissemination of scholarship, and setting and maintaining the boundaries of disciplines, as well as their perspectives on the imbalances of global knowledge production. This article reports on a pilot project which set out to shed some light on these views. As editors of two peer-reviewed journals in the fields of journalism and journalism studies, the authors initially drew upon their own experience to identify common issues facing journal editors. An online questionnaire was distributed to the editors of 24 journals in the fields of communication, journalism and journalism studies. The responses received suggest that journal editors are not only conversant with a plethora of complicated and vexing problems, but have also developed a range of successful strategies for responding to them. At the same time, however, publication - or, rather, non-publication - of papers authored in the Global South remains a contentious issue that produced divergent responses.

\section{Mass market and popular literature publishing}

Maillu, David “Popular Fiction Publishing in Africa: Does it Have a Place?" In Coming of Age. Strides in African Publishing. Essays in Honour of Dr. Henry Chakava at 70, Nairobi: East African Educational Publishers, 2016, 95-105.

David Maillu, the well-known Kenyan writer and publisher of African popular fiction, in a contribution to a Festschrift published in honour of Henry Chakava, pays tribute to Chakava's contribution to the birth and development of African pop fiction through the launch of Heinemann's 'Spear Book Series' back in the 1980s. Maillu asks "when does a work of fiction become popular or serious? Who decides what qualifies for popular or serious fiction?" Every genre has its own conventions, he says. Contrary to what some Western scholars have written about African popular fiction, he defines it as "using simple words to address serious social-economic immoralities and keeping society in check." African popular fiction, which has attracted a measure of criticism in the past, has a long history and its future is promising, Maillu says, especially in the digital age, with new delivery methods for content on mobile devices. "Its foundation is in the history of African traditional style of expression."

Petersen, Kierran Amid Religious Violence, Nigerians are Writing Steamy Romance Novels.

https://www.pri.org/stories/2016-04-06/nigerians-are-writing-steamy-romance-novelsescape-religious-violence (Posted 12 April 2016) [20/05/16]

Not far from the epicentre of religious violence in Nigeria, a romance novel industry is booming. Written in Hausa, the work of mostly female authors and written for women, the books shift between morality tales and classic pulp romance. Often written by hand in small 
composition books, the books are sold in crowded marketplaces, where you can buy thousands of different titles for as little as 50 Naira (US\$0.15). Often serialised, a few of the stories are also transcribed and published online. They books are called littattafan soyayya, which roughly translates to 'love literature.' The thriving littattafan soyayya industry has recently become the subject of photographer Glenna Gordon's Diagram of the Heart http://www.glennagordon.com/diagram-of-the-heart/ about Muslim women and romance novels in Northern Nigeria, and which was chosen as one of the New York Times Magazine's best photo books of the year (see also http://lens.blogs.nytimes.com/2015/10/19/glennagordon-diagram-of-the-heart-open-society-foundation/?_r=0.) While hugely popular, the books are also controversial. Some local governments in Northern Nigeria have censored the books and in 2007 the state governor of Kano publicly burned many books that he said were 'pornographic', corrupting young people, and encouraging moral indecency. Nowadays authors are compelled to register with Hisbah, the morality police in Kano, and that censorship board often removes writers' steamier scenes.

Note: Among other short articles and stories on this interesting topic, see also Fifty Shades, Sahel-style.

Northern Nigeria's Subversive Love Literature The Economist 08 October 2016

http://www.economist.com/news/middle-east-and-africa/21708268-northern-nigerias-subversive-love-

literature-fifty-shades-sahel-style [15/12/16]

and

The Subversive Women Who Publish Self-published Novels Amid Jihadist War by Laura Malonee

https://www.wired.com/2016/02/glenna-gordon-diagram-heart/ (Posted 08 April 2016) [15/12/16]

\section{Open access publishing and licensing (see also $\rightarrow$ Scholarly publishing)}

Butcher, Neil; Sarah Hoosen, Lisbeth Levey, and Derek Moore The Impact of Open Licensing on the Early Reader Ecosystem. Randburg, South Africa: Neil Butcher \& Associates, 2016. 125 pp.

http://www.nba.co.za/sites/default/files/Early\%20Literacy\%20and\%20Open\%20Licensing. formatted.pdf [03/09/16]

Funded by The William and Flora Hewlett Foundation, this is a report about a research study that examines how to use open licensing to promote quality learning resources for young children in sub-Saharan Africa (and in low-income countries elsewhere) that are relevant and interesting. Research in early reading tends to focus on traditional publishing value and supply chains, the authors say, without taking much consideration of new approaches and solutions emerging from the digitization of content and the impact of open licences. Production innovations considered here include content creation models, storybook management and storage, and printing and distribution, all of which are evolving rapidly as new technologies are developed and applied. The report also describes and assesses how major players in the early reader ecosystem impact on the production and utilization of quality resources. These include publishers, NGOs, libraries and literacy organizations, and donors. In addition, because cost models for open licensing any resource are different from commercial publishing, the report examines how open licensing and cost recovery can be effectively addressed in order to promote the long-term sustainability of local content creation, production, and utilization. Finally, the report offers a detailed set of implications for early literacy content creation and utilization in low-income countries, which should underpin the development of creative ways to deliver books to young children. The report is 
supplemented by a series of appendices, which seek to capture in more detail the findings of the study's research processes.

In their conclusion the authors state: "This report has explored how digital disruption and open licensing are transforming the world of publishing, with examples of how these changes might be harnessed to find sustainable solutions to the seemingly intractable problem of supplying enough high quality early literacy storybooks to young children in low-income countries to enable them to acquire effective literacy skills. While none of these innovations, in their own right, provides a full solution to this challenge, it is clear that they do significantly think through how to harness open licensing within the framework of viable new business models in a context where those business models are not yet well understood or fully developed. What does seem clear is that funding strategies, whether initiated by governments or donor agencies, that adopt a 'business-as-usual' model to early literacy storybook supply, investing solely in traditional publishing value and supply chains, will simply replicate the many well documented failures of the past. Likewise, initiatives that focus only on short-term targets like numbers of stories produced or numbers of books distributed will do nothing to solve the underlying challenges of long-term sustainability of the cultural industries in low-income countries on which sustainable literacy for all are inevitably dependent. Thus, although digital disruption and open licensing do not, by themselves, solve these supply problems, they offer exciting new opportunities that merit systematic testing and scaling in order to enable them to achieve their full potential."

Council for the Development of Social Science Research in Africa (CODESRIA)

Dakar Declaration on Open Access in Africa and the Global South. http://wiki.lib.sun.ac.za/images/5/50/Dakar-declaration-2016.pdf [14/12/16]

The 4th CODESRIA Conference on Electronic Publishing and Dissemination was held in Dakar, Senegal, from 30 March 30 to 1 April 2016, and focused on Open Access in Africa. This is a two-page declaration issued at the close of the conference, which states, inter alia: "Open Access leverages the combined power of scholarly information and technology to serve the public good, but it has not been fully harnessed in Africa and the Global South."

Note: For a summary and highlights of the conference see also http://www.eifl.net/news/dakar-declarationopen-access, and for the complete list of papers (a number of which are also individually listed in this literature review) see http://www.codesria.org/spip.php?article2564\&lang=en.

Du Toit, Ina Maria Towards a Sustainable Open Access Scholarly Publishing Model in the South African Context. Pretoria: University of Pretoria, MIS Dissertation (Publishing), 2015. $197 \mathrm{pp}$.

http://www.repository.up.ac.za/dspace/handle/2263/49613 [12/09/16]

Based on an extensive literature survey that aimed to identify and define business models used in open access scholarly publishing in the international context, this MIS dissertation makes a range of suggestions towards sustainable open access scholarly publishing by identifying and exploring the various factors associated with open access models in South Africa, and considering the roles of all the role players towards output of high quality research articles. The study discovered that South African scholarly publishers find the shift from a traditional subscription model to an open access model difficult, "because they are not addressing their new client segment and also not acknowledging their own expertise 
within the publishing cycle." The research also indicated, the author states, "that the approach of either subscription or open access hinders a sustainable open access publishing model, but that the publishing community should instead encourage an approach a publishing environment that allows for both of these models to exist and function. Open access should not replace the traditional model but instead, enhance it."

\section{Gray, Eve/OpenUCT Initiative Project Open Access and African Research Publishing in} the 21st Century.

http://openuct.uct.ac.za/open-access-and-african-research-publishing-21st-century (no posting date) $[15 / 07 / 16]$

What needs to be done to achieve an enabling policy environment and the necessary technical infrastructure and professional skills in Southern Africa to foster the effective communication and publication of African scholarship? And what benefits would accrue from more effective communication of the scholarship in the region? What would the region gain? These were some of the core questions explored by a variety of speakers at a Leadership Dialogue attended by southern African Vice-Chancellors and organized by the Southern African Regional Universities Association (SARUA), at which the OpenUCT Initiative Project unit in Cape Town http://openuct.uct.ac.za/ was a joint sponsor. This blog posting draws attention to some key points on how policy change could be best achieved, and what the policy environment could look like.

Gray, Eve Open Access and the Decolonization of the University in Africa. http://www.slideshare.net/evegray/oa-and-the-decolonization-of-the-university-in-africa2016 [20/01/17]

A SlideShare presentation made at the 4th Codesria Conference on Electronic Publishing and Dissemination, Dakar, 30 March-1 April 2016. Open access in Africa appears to be heading for stormy weather, Eve Gray forewarns, and that instead of decolonizing OA it is in danger of losing out to the corporate strength of the big journal publishers and their hold on academics keen for promotion. One weakness of the OA movement has always been ideological arguments about the right road, the Green or the Gold, and may have helped to bring about this situation. The weakest point has been researchers' addiction to prestige journals and impact factors, Gray says. She draws attention to an announcement by publishing giant Elsevier that they were sponsoring the development of an open access African megajournal, in collaboration with the African Academy of Sciences, the African Centre for Technology Studies, the South African Medical Research Council, and IBM Research Africa. (See also http://www.gray-area.co.za/2016/06/23/an-elsevier-africanmegajournal-proposal-re-colonizing-the-university-in-africa/) “Despite the claim by Elsevier that the policy advances sharing, it actually does the opposite. The policy requires authors to apply a 'non-commercial and no derivative works' license for each article deposited into a repository, greatly inhibiting the re-use value of these articles ... Furthermore, the policy applies to 'all articles previously published and those published in the future' making it even more punitive for both authors and institutions. This may also lead to articles that are currently available being suddenly embargoed and inaccessible to readers." And this is only one of many African-centred initiatives by the multinational publishers "who until now have denied that Africa is part of their 'international' world, and therefore capable of offering research impact." Meantime, as the OA debate continues, key 
questions remain the same: Who owns scientific information? How much does it cost to access it? Who should be able to access it?

Human Sciences Research Council Open Access Publishing in the Contect of HSRC Press Based in Cape Town, South Africa. http://www.codesria.org/IMG/pdf/codesria_conference_on_electronic_publishing_poster_ presentation_hsrc_press_shoaeane.pdf?4790/49ff550f012295d52a8458d9968cf8adef8faf7b [14/12/16]

A short presentation describing the context and the dual-medium business model adopted by HSRC Press in South Africa, including methods of tracking and results monitoring, and the use of digital platforms.

Kitchen, Stephanie Open Access Practices of Selected African Studies Journals. http://www.codesria.org/IMG/pdf/kitchen.pdf?4786/358cb1f999d8fba755864d7afd867d46a a7ffc8c [14/12/16]

Providing an overview of Open Access (OA) developments in African studies and anthropology journals, this paper discusses the progress of ten, mainly British, Africanist journals in extending access using some of the criteria set out in John Willinsky's landmark study The Access Principle. The paper also explores some alternative OA cooperative models that mobilise larger scale economies, but whose sustainability remains to be tested in the longer term. Stephanie Kitchen suggests that the development and aggregation of institutional repositories may offer a faster route to green OA for journal articles in both Africa and the UK, as well as making other publication types, including research theses, available online. However "book and journal publication will likely retain their place as cornerstones of the advancement of knowledge and scholarship. Although some disciplines have seen increased publications by African authors from the continent and the diaspora, exclusion and marginalization of African authors from international research, and the dearth of African editors on the leading journals, still need to be acknowledged."

In her conclusion, the author states: "In most African countries, library funding, whether for subscriptions, OA publication charges, cooperative models, or repositories, is a major issue. It is unlikely that cooperative OA models would transfer to Africa without supporting library resources. The work of AJOL [African Journals Online] has demonstrated the fundamental resource scarcity of African journals whatever the publishing models whether subscriptions or OA. ... Many African studies journals are already available freely or at reduced rates electronically as part of consortia arrangements in African and other lowincome countries. Such access programmes will remain important and their impact should improve as Internet coverage is expanded. However, availability does not correlate with access in a straightforward way. Such schemes, along with the OA initiatives taken by the journals sampled here, do not address deeper access and knowledge production problems prevalent in historically disadvantaged communities."

Okemwa, Ondari Open Access, Scholarly Publishing and Knowledge Production in SubSaharan Africa: Opportunities and Challenges. http://www.codesria.org/IMG/pdf/okemwa.pdf?4785/859d56cb2c6e74f23258e1ed669568ceb d71b6e6 [14/12/16] 
This paper "looks at open access as a new mode of scholarly communication which may address most, if not eventually all the problems which confront scholarly publishing in subSaharan Africa." It also discusses some of the current challenges of scholarly publishing in Africa, and the advantages, and constraints, of open access publishing.

\section{Publishing in African languages (see also $\rightarrow$ Reading culture and reading promotion)}

Julius, Clare-Rose, and Hans Pienaar Interview: African Languages in the South African Publishing Industry. http://www.litnet.co.za/interview-african-languages-south-african-publishing-industry/ (Posted 20 June 2016) [15/07/16]

Clare-Rose Julius is Distribution \& Marketing Manager at Porcupine Press in South Africa http://porcupinepress.co.za/, a self-publishing company that supports authors in the production and distribution of high quality books. She is also one of the founding members, as well as the director, of the not-for-profit company African Narratives http://www.africannarratives.org.za/, that promotes the development of independent publishing and grassroots literature in South Africa. In this interview she talks about the challenges of publishing in mother tongue languages: problems of standardizing some indigenous languages, a lack of demand of books in African languages, the reluctance of bookshops in stocking such books, a low reading culture, the lack of both state and industry support, and VAT charged on books. While distribution into local markets and communities remains a major problem, Clare-Rose sees some promise, at least in the urban areas, in the proliferation of informal book traders and street hawkers: "that kind of informal trading of books exists already on the ground, there is a definite need and opportunity to expand it right across South Africa. And this can basically be the key to the accessibility of books to people, and everyone in the local communities in South Africa."

\section{Möller, Jana Multilingual Publishing: An Investigation into Access to Trade Books}

Through the Eleven Official Languages in South Africa. Pretoria: University of Pretoria,

2015. MIS dissertation (Department of Information Science). 230 pp.

Online:

http://repository.up.ac.za/xmlui/bitstream/handle/2263/45945/M\%C3\%B61ler_Multilingual _2015.pdf?sequence=1\&isAllowed=y [29/12/15]

This MIS dissertation aims to investigate the shifts that have taken place in the multilingual trade publishing sector in South Africa, and to what extent constitutional ideals of language equity have been implemented to multilingual publishing to improve access to trade books in the country. Using a combination of primary and secondary research, it examines the disconnect between these constitutional ideals and current practice of publishers. The author notes that "today, there are few African language books available for leisure reading for adults, and this means that the eleven official languages are not being treated or developed equally", a claim supported by an analysis of the Publishers Association of South Africa's book industry reports, which provide figures of the sales of books in different languages and from the different publishing sectors. The government is aware of the lack of African language books being read for leisure, and is currently attempting to improve the picture. However, the author argues that a lack of implementation of the government's language policy, as well as its national book policy, may further delay the realisation of 
constitutional ideals. The study concludes that there is no clear-cut solution to improve the situation, but recommends a range of changes in various areas connected to book publishing and book reading, over an extended period of time.

Muoh, Obinna U., and Chukwuka Z. Ezinwanne "Publishing and Literacy Development in Africa's Indigenous Languages: The Igbo Example in Nigeria." Developing Country Studies 6, no. 4 (2016): 19-29.

http://www.iiste.org/Journals/index.php/DCS/article/view/29895 [29/08/16]

Language is not just a vehicle of cultural expression, but can also be seen as an important symbol of social and political identity of any group, and publishing provides a dominant signifier of such language. Publishing in Africa has been dominated by the colonial languages, notably English and French. Thus colonial enterprise and legacies have resulted in the suppression of publishing in Africa's indigenous languages. Yet, the authors state, there is a consensus among many scholars that literacy and associated publication in first languages not only influences the nature of education, but also promotes cultural identity. This paper examines the historical dynamism of literacy and publishing in the Igbo language (one of the three major languages and cultural groups of Nigeria) in the context of the social and political developments in 20th century Nigeria. The authors argue that the fragility and problems of publishing in Igbo language was responsible to the dwindling interest in reading, writing and speaking of the language. The paper "interrogates the distinction between indigenous publishing in Africa and publishing in African languages. It recognizes the various challenges that confront indigenous language publishing in Africa, such as lack of clear-cut language policy in most African countries, multiplicity of languages and dialects, and limited markets for published material in the indigenous languages. It posits that addressing these problems and embracing the opportunities in indigenous language publishing and literacy development will contribute in understanding the dynamics of Africa's intellectual history."

\section{Reading culture and reading promotion (see also $\rightarrow$ Publishing in African languages)}

Note: books and articles devoted to literacy, teaching reading, or developing reading skills, are not included here.

bafyngracey [pseud.] Influencing the Reading Culture in Uganda. https://nabunyaelizabeth.wordpress.com/2016/11/15/influencing-the-reading-culture-inuganda/ (Posted 15 November 2016) [25/11/16]

Nyana Kakoma, the director and founder of Sooo Many Stories http://somanystories.ug/ in Kampala, reflects on literature, children's books, the need to develop a lively reading culture in Uganda, and the activities of her recently founded publishing house.

\section{Batenga, Pamela Market Survey for Ugandan Literature in Uganda.}

https://www.scribd.com/document/324894127/Femrite-Survey-Report-on-UgandanLiterature\#from_embed [28/12/16]

This report and market survey released by the Uganda Women Writers Association (Femrite) challenges the commonly held view that Ugandans do not read. In her Powerpoint presentation the author asserts that Ugandans do read, and that local publishing output has 
increased significantly, but reading books is facing heavy competition from TV, the Internet, and social media. Poverty and school systems that do not encourage reading, sometimes ineffective marketing by publishers, and not enough government support for reading, writing, and publishing initiatives, are additional factors that undermine the growth of the reading habit in the Uganda. The report offers a number of recommendations how to improve the reading culture in the country, which includes the construction of community libraries through support by the government, as well as encouragement of increased production of local language books.

Coovadia, Imraan; Cóilín Parsons, and Alexandra Dodd Relocations: Reading Culture in South Africa. Cape Town: University of Cape Town Press, 2016. 256 pp.

Between 2009 and 2012, the Gordon Institute for the Performing and Creative Arts in Cape Town held the Great Texts/Big Questions public lecture series, which became a celebrated part of Cape Town's cultural landscape, demonstrating current intellectual and creative thinking in South Africa. These lectures gave audiences a chance to engage with transformative texts and questions, to hear thought leaders speak on the ideas, the books, the art, and the films that matter to them and to us. Relocations: Reading Culture in South Africa brings together a selection of these lectures by world-renowned artists, writers and thinkers in the form of essays, for the benefit of a wider readership, with a contemporary design which plays with words. [Not examined, publisher's blurb]

Edwards, Viv Nal'ibali Reading-for-Enjoyment Campaign Telling Tales: The Story of the Nal'ibali Reading-for-Enjoyment Supplements. Cape Town: Project for Alternative Education in South Africa (PRASEA), 2014. 11 pp.

http://www.praesa.org.za/files/2014/04/Telling-Tales-The-Story-of-the-NalibaliSupplements.pdf [03/04/16]

An evaluation of the bilingual reading-for-enjoyment newspaper supplements scheme, which is part of the Nal'ibali ("Here's the story" in Xhosa) campaign http://www.nalibali.org/, a campaign that starts from the premise that stories - oral and written - are as important for literacy development as the more technical aspects of learning to sound or spell out words, write neatly and do grammar. The author finds that the achievements of the Nal'ibali supplements in the first two years of operation are impressive. The project produced approximately 11 million supplements in total, including 85 bilingual stories. With just over 200,000 copies each week reaching subscribers and reading clubs in five provinces, a large following of readers, very many of whom would not normally engage in activities around reading with children, now regularly looks forward to receiving the next supplement, and using it in many different ways. "Single-handedly, Nal'ibali has made accessible, to a huge audience and at very low cost, unprecedented numbers of stories in African languages." Teething problems associated with distribution of the supplements to reading clubs are likely to take some time to resolve, and issues related to extending reach also need close attention. "Yet, when all is said and done, Nal'ibali has clearly created a template for delivering children's stories in African languages and English that reinforces a message of fundamental importance: reading is useful, meaningful and enjoyable. When children enjoy reading, they read more. The more they read, the better they become." 
Ekedahl, Jennie, ed. Advancing the Right to Read in Rwanda. Programme Baselines and

Studies. Summary Report. London: Save the Children, 2014. 33 pp.

https://www.savethechildren.org.uk/sites/default/files/docs/Advancing_the_Right_to_Rea

d_in_Rwanda1.pdf [05/11/2016]

This insightful report contains findings from nine different baselines and studies carried out for Save the Children Rwanda's Advancing the Right to Read programme. Launched in 2013, the programme aims to reverse the global crisis in learning by providing a continuum of services for children aged zero to nine years, focused on supporting pre-school and early primary literacy skills to ensure all children leave school able to read. The Rwandan Children's Book Initiative is being implemented in Burera district and at national level is operated in collaboration with the Rwandan publishing industry.

Many interesting findings were derived from the baseline surveys, for example: The probability of children reading "is highly influenced by the home environment. Parental reading habits and socio-economic status seem to predict if a child will read or not. Findings also show that if a mother reads, a child in a household with low socio-economic status has the same probability of reading as a child in a household with high socio-economic status where the mother does not read. .... Despite the seemingly limited scope for reading in the home, the Home Literacy Environment study documented overwhelmingly positive beliefs about reading and learning among parents and community members." The study identified several obstacles to the production of high-quality reading materials in Rwanda. "First, the publishing industry in general lacks knowledge on what constitutes a good book for children and publishers lack a solid understanding of the quality criteria and attributes required for high-quality storybooks for all levels. The absence of degree programmes to train publishers means that many Rwandan publishers do not undergo any formal professional training and are often not sufficiently knowledgeable about the fundamental elements of various types of high-quality children's texts."

Local printing costs are prohibitively high, and local printers do not have the capacity to print large quantities of books that fulfil the REB's technical specifications. Until recently, there has been an overall absence of legal and institutional frameworks for the publishing sector and for the expansion of a network of community libraries. However, a National Policy for Library Services has recently been created, and a National Book Development Policy is also under development, which is expected to support the functioning of a stronger publishing sector in Rwanda, producing a regular supply of Kinyarwanda language supplementary reading materials.

\section{Kevane, Michael K. Reading Fiction and Economic Preferences of Rural Youth in Burkina} Faso.

http://scholarcommons.scu.edu/cgi/viewcontent.cgi?article=1054\&context=econ [27/01/17] Presents the results from a reading programme for youth living in villages in southwestern Burkina Faso. Standard experimental games were used to measure the effects of increased reading of fiction on several attitudes and preferences important for economic development. After six months of access and encouragement to read appropriate young adult fiction, there were few differences in any of four measured outcomes (trust, contribution to public goods, risk, and patience) between those participating in the reading programme and the control group. Many have hypothesized that fiction would have significant effects on the values and 
preferences of readers, and "advocates of fiction have argued that readers develop better intuitions about the interior lives of themselves and of others."

However, in his conclusion the author asserts that "the results presented in this paper suggest some scepticism about how much reading fiction affects people's economic preferences. If one's prior belief was that these effects were large, then that belief should perhaps be revised downwards. The reading programme implemented in villages in southwestern Burkina Faso had the desired effect of increasing the availability of young adult reading material, and there was much qualitative evidence that readers enjoyed reading the novels. But the increased reading seemed to not have any significant effects, either in the statistically significant sense or in terms of magnitudes of effects. The effects estimated were generally very small, and thus not statistically significantly different from zero. ... So, the results here should be interpreted as being that a realistic reading programme generated no sizable change in economic preferences. An extraordinary reading programme certainly might have large effects." The author further suggests that the zero results presented in the study suggest the need for more research on this question, as countries in sub-Saharan Africa devote public resources to fund reading promotion programmes in and out of school.

\section{Mushimiyimana, Diane Rwanda: How Local Writers, Publishers Are Trying to Cultivate Reading Culture. http://allafrica.com/stories/201611020073.html (Posted 02 November 2016) [06/11/16]} Ministries of Education, and Sports and Culture and other players in Rwanda have been encouraging local writers and publishers to write and publish more books in local languages to fill the existing gap of Kinyarwanda reading materials. Initiatives like 'Andika Rwanda', an annual national competition for writing children's stories and poems, have had significant impact on the children's book industry in Rwanda. 'Andika Rwanda' gives children with writing talent a chance to get their books published and later distributed in schools. More than 20 publishing companies are currently operating in Rwanda, and creating children's books are a priority for almost all of them. However, as a budding industry, local publishers are facing many challenges that require concerted efforts between the government and other concerned stakeholders to address. The government's role is mainly in awareness campaigns, and providing professional training and organizing workshops.

Paper Manufacturers Association of South Africa Printed Books are Best When Reading to Children.

http://www.thepaperstory.co.za/2016/04/printed-books-are-best-when-reading-tochildren/ (Posted 19 April 2016) [28/04/16]

To mark World Book Day on 23 April 2016, the Paper Manufacturers Association of South Africa (PAMSA) here explores the topic of reading by gathering the opinions of South African professionals and parents about the value of reading to children from paper books. It argues that "reading to children from an early age is an acknowledged factor in early childhood development (ECD), as it not only strengthens the bond between adult and child, but helps little ones develop cognitive and conversational skills." The digital world has pros and cons, it says, and so it not surprising that a debate on the merits and pitfalls of e-books against the printed page wages on. Tablets take away true engagement: "Touch-screens are 
great at a lot of things, but engaging children in a narrative is not one of them. Why? Because interactivity stops young ones from falling in love with stories and reading for pleasure, the cornerstones of imagination and understanding." A digital device makes it very easy for a child to dismiss reading as 'boring' in comparison with the instant gratification of games and apps. But there are simply too many distractions: "Children are most likely to engage with stories in the right environment and context, and that means away from a screen." It suggests that "parents should encourage a balanced mix of online and offline reading, both for older children reading by themselves and for toddlers who need guided reading to provide them with the necessary mental space to engage with a story in a deeper way."

Snyman, Maritha E. A Longitudinal Study of a Reading Project in the Northern Cape, South Africa. Reading and Writing. Journal of the Reading Association of South Africa 7, no.1 (2016)

http://www.rw.org.za/index.php/rw/article/view/85/234 [27/01/17]

Reading is in decline in South Africa, and journalists and educationists alike comment about and lament the dangerously low levels of South African learners' reading skills. The topic of this longitudinal study was reading promotion and its perceived benefits. The aim was to determine if reading promotion can lead to reader development, and if reader development can lead to self-development, as is often claimed in the literature. A reading promotion project in the Northern Cape, South Africa, was monitored over a period of five years by using a selection of qualitative and quantitative data collection methods. The outcome of the study indicates that the reading promotion project was responsible for positive changes in the lives of the beneficiaries of the intervention. It especially points to the positive role access to appropriate reading material and prolonged and enthusiastic reading motivation can play in the lives of a developing community with little means. In her concluding remarks the author states: "It is possible to create a reading culture where none exists, but creating a reading promotion project that continues to foster a reading culture needs time, money and mostly enthusiasm. This research has further shown that South Africa has the human capital and that good leadership can unlock it."

Temple, Charles, and Firas Elfarr Reading CODE: Assessing a Comprehensive Readership Initiative in Tanzania.

http://www.codecan.org/sites/default/files/research_brief_reading_code_nov_2015.pdf [18/03/16]

A comprehensive readership initiative offered by CODE-Canada works with local partners in Africa to provide culturally-relevant and engaging books that young people will want to read; supports libraries to distribute and care for books; and shares methods of instruction to help teachers engage children meaningfully with books to build their fluency and comprehension, especially their higher order comprehension and critical thinking. Reading CODE programmes are currently active in Ethiopia, Ghana, Mali, Tanzania, Kenya, Mozambique, Liberia and in Sierra Leone. The effectiveness of such a literacy intervention, using teacher training, book provision, and library support for primary schools in central Tanzania, is evaluated in this research brief. It found that after a four-year project that assisted 350 teachers to promote contextualized word study, fluency, comprehension, and writing - and was supported by locally written and engaging books - children in project 
schools showed substantially superior performance on every measure compared to a demographically-matched comparison group of children.

Scholarly publishing (General) (see also $\rightarrow$ Journals and magazine publishing, $\rightarrow$ Open access publishing and licensing, $\rightarrow$ Scientific, medical and technical publishing)

The Academic Book in the South, 7-8 March 2016, British Library. https://storify.com/AcBookFuture/the-academic-book-in-the-south [10/09/16]

Organised by the British Library in collaboration with Professor Marilyn Deegan (The Academic Book of the Future Project) and Dr Caroline Davis (Oxford Brookes University), this two-day conference discussed "how profound changes in publishing will affect the academic book of the future in the global South", and explored the production, dissemination and reception of scholarly publications in the countries of the South, particularly in Africa, the Middle East and South Asia. An account of the whole conference has been created from tweets by delegates, and which is accessible at the above Livefyre Storify page.

A summary of "the main messages" in the areas of publishing, access, and digitisation The Academic Book in the (Global) South by Lesley Pitman, can be viewed at https://blogs.ucl.ac.uk/libnet/2016/03/21/the-academic-book-in-the-global-south/ (Posted 21 March 2016) [10/09/16]

Video recordings from the conference are available as follows:

The Academic Book in the South, Day 1 Panel 1: Academic Authorship and Knowledge Production

https://www.youtube.com/watch?v=nxxsE7N9y7Y (Video recording 1:08.58) [10/09/16] The Academic Book in the South, Day 2 Panel 1: The Role of Libraries and Archives https://www.youtube.com/watch?v=ccYzrVnL3L4 (Video recording 58.8mins) [10/09/16] The Academic Book in the South, Day 2 Final Panel: Discussion \& Concluding Comments https://www.youtube.com/watch?v=G95vOJ2MWnw (Video recording 1:00.44) [10/09/16] The Academic Book in the South: Abhijit Gupta and Padmini Ray Murray https://www.youtube.com/watch?v=AMoZ6ikrv0s (Video recording 1:10.25) [10/09/16] This concluding session considered the prospects of the academic book in the global South, and evaluates new directions in authorship, publishing and reading of the academic book.

Also of interest are two blog postings by members of the Digital Humanities Student Society at King's College, London

Recap: Academic Book in the South, Day 1 by Maria Kaffa https://dhsociety.org/2016/03/18/recap-academic-book-in-the-south-day-1/ (Posted 18 March 2016) [10/09/16]

Recap: Academic Book in the South, Day 2 by Michaela Doyle https://dhsociety.org/2016/03/22/recap-academic-book-in-the-south-day-2/ (Posted 22 March 2016) [10/09/16] 
Alemna, Anaba A. Scholarly Publishing in Africa and the Role of the Open Access

Initiative (OAI). Accra: Ghana Academy of Arts and Sciences (Annual Lecture in the Humanities), 2016. 29 pp.

http://ugspace.ug.edu.gh/handle/123456789/8508 [06/09/16]

Scholarly publishing in Africa is still struggling to keep pace with the rest of the world, for a variety of reasons, some of which are examined in this article. The high mortality rate of journals in Africa is a cause for concern. This is one of the major reasons why researchers in Africa seek to publish their findings abroad. Much of the research outcomes emanating from African universities achieve poor visibility due to lack of high quality indigenous s journals. The alternative is "that African academics strive to publish in internationally renowned peer-reviewed journals in order to ensure academic promotion, but then, again, not many of these do make it into such journals. And when they do, the journals are out of reach of most university libraries, rendering access difficult." As a result of these difficulties some African academics have published in exploitative predatory journals of dubious quality and integrity. As one of the solutions to these problems, the author suggests that scholars in Africa should take advantage of the opportunities and benefits of Open Access (OA) Journals.

\section{Le Roux, Elizabeth "Discrimination in Scholarly Publishing." Critical Arts. South-North} Cultural and Media Studies 29, no. 6 (2015): 703-784.

http://dx.doi.org/10.1080/02560046.2015.1151104 (free access) [10/08/16]

The introduction to a special issue of Critical Arts, which examines the perceptions and realities of discriminatory practices in academic and scholarly publishing in South Africa. "Studies conducted internationally, including in the United States, the United Kingdom and Sweden, indicate that discrimination does take place against women and ethnic groups in scholarly publishing. Discriminatory practices may include, amongst others, unfair reviewing and exclusion from 'old boys' networks. The values that underlie the scholarly communication system - such as the maintenance of 'high standards' - may also function to exclude South Africa's system of accrediting journals, which in effect creates tiers of journals, exacerbates existing inequalities in the global knowledge production arena."

Le Roux, Elizabeth “Open Minds and Closed Systems: An Author Profile of South Africa's University Presses." Critical Arts. South-North Cultural and Media Studies 29, no. 6 (2015):

746-765.

http://www.tandfonline.com/doi/abs/10.1080/02560046.2015.1151110 (subscription

based/pay per view) [12/09/16]

Provides an overview of author selection at South Africa's most prominent scholarly publishers, its university presses, through a case study of author profiles of Wits, Natal (now KwaZulu-Natal), Unisa and Cape Town. It is "an attempt to provide basic data to underpin perceptions of discrimination in the selection of books for publication." The author analyses the author profile of the presses to consider whether the historical record suggests that there has been discrimination in the selection of books for publication. She argues that systemic, socio-political barriers had a greater impact than peer review systems on the publication of marginalised groups during the apartheid era. The author's profiles of these university presses do indicate some change over time, towards greater diversity in terms of both race and gender. However, women and black authors - and black women authors in particular remain under-represented. 
Moletsane, Relebohile; Louise Haysom, and Vasu Reddy “Knowledge Production, Critique and Peer Review in Feminist Publishing: Reflections from Agenda." Critical Arts. SouthNorth Cultural and Media Studies 29, no. 6 (2015): 766-784.

http://dx.doi.org/10.1080/02560046.2015.1151112 (subscription based/pay per view) [10/08/16]

Aiming to provide basic data to underpin perceptions of discrimination in the selection of books for publication, the authors consider how Agenda http://www.agenda.org.za/, a feminist journal of the Global South, and Africa specifically, balances the demands of peerreviewed knowledge production with prerequisite gender, race and space/place equality in the context of mechanisms that often privilege particular ways of knowing. The article addresses a range of questions, such as: "What forces inhibit and marginalise women's voices generally, and black women's voices in particular, from feminist knowledge production and dissemination? How do we sustain our feminist positioning and critique in publishing in an environment where gender equality in the various socio-economic spheres of life remains elusive and where gender violence against women is rife, and this in the context of 'scholarly' peer review? In particular, how do we ensure that the voices of those most marginalised by these inequalities and social forces are heard in ways that matter and, indeed, count - in scholarly publishing?"

Tomaselli, Keyan "Practices in Scholarly Publishing: Making Sense of Rejection." Critical Arts. South-North Cultural and Media Studies 29, no. 6 (2015): 713-724.

http://www.tandfonline.com/doi/abs/10.1080/02560046.2015.1151107 (subscription based/pay per view) [10/08/16]

In South Africa, criticisms of peer review often hinge on allegations of racism, anti-African attitudes, and viewpoint discrimination. This article discusses the issue of peer-review, and examines these allegations in terms of claims of Western conceptual gatekeeping. Cautions are offered on allegations of exceptionalism, as are some strategies on dealing with the process of peer review.

\section{Uduku, Ola Notes on the Future of the Academic Book in Africa.}

https://academicbookfuture.org/2016/04/05/academic-book-in-africa/ (Posted 05 April 2016) [15/04/16]

This guest blog post is a rejoinder to the Academic Book in the South two-day conference held at the British Library on 7-8 March 2016 (see preceding records in this section) as part of the Academic Book of the Future Project https://academicbookfuture.org/. Academic books in Africa, Ola Oduku says, "despite being produced and available for at least half a century, are now a rare sight to behold in the continent's academic institutions. Locally-authored academic books are even harder to find." The author (a Reader in Architecture and Dean International for Africa at Edinburgh University's School of Architecture and Landscape Architecture) aims to "explore the spaces which books and readers inhabit and then consider what books are being written and published, and what kind of future both academic publishing and the physical book might have in Africa." On a recent visit to libraries at the Kwame Nkrumah University of Science and Technology and Legon University in Ghana, she found that while reasonably well-maintained, furnished, and staffed, "library stacks are sparsely stocked, holding some editions of historic textbooks, but rarely any up-to-date journals or printed matter. Unsurprisingly there are few students using the library reading spaces for study - proportionally it seems there are often more 
staff than users of these libraries." In most African universities, for career advancement and promotion, academic books often are less critical than the refereed academic paper, and Oduku argues that "in Africa, publishing itself takes significantly more time to achieve with the vagaries of production, editing, and printing in the African setting. There are of course publishing houses in Africa, but their focus is not on academic book publishing."

So what might the future look like for academic publishing in Africa? "If we start from the premise that academic material for student study will need to be provided, and the current system of distribution, via the academic textbook, either individually purchased or available for loan via university library outlets, is flawed and no longer works, then we need to explore what the future learning landscape might be." The author envisions ICT-linked classrooms and new forms of library facilities where students can learn through networked cheap personal tablet readers to which material is downloaded in 'packets', small units of material, such as chapters in books or homework/task exercises, which can be downloaded by students using mobile devices, and which at the same time gives the responsibility of the hardware required for online access to the students and users of the material. There would also be a need to developing local writing centres and support programmes for writing. "This would mean that there would be less dependence on programmes from abroad or occasional workshops, and could result in the development of an African academic writers network, likely to be in association with African publishers. Thus an academic 'hub for writing and publishing' at larger universities or at regional level would be a possible way forward, to be refined to best suit the needs of regional or large universities."

van Schalkwyk, Francois African University Presses. An African Minds Research Project. https://www.academia.edu/29291359/African_University_Presses [08/12/16]

A presentation made at the African Studies Association of the UK (ASAUK) biennial conference held in Cambridge in September 2016. It forms part of two-year research project "African University Press in a Digital Age: Practises and Opportunities", supported by the Carnegie Corporation of New York (see also http://www.africanminds.co.za/africanuniversity-presses/). Its major objective was to investigate how African university presses are positioning themselves in relation to new global opportunities and challenges, while at the same time examining the institutional and other constraints faced by university presses in Africa. The study is based on a baseline survey of university presses in Africa and indepth interviews with selected university presses. The author says that "it is hoped that a pragmatic set of recommendations will emerge; recommendations that are simultaneously attuned to the opportunities and the everyday realities of African university presses."

This is an interesting study, albeit presenting a rather dismal picture: A detailed table in the presentation (see link to full dataset below) indicates that there are 52 established university presses on the African continent. However many are dormant and are not publishing new work at this time. Only seven presses published in 2015 and four in 2014. Twenty-seven institutions have websites (of which nine presses have their own web pages), but only twenty-one have current email addresses. According to the presentation, responsiveness to email enquiries was generally poor, with $47 \%$ of emails sent remaining unopened, and $21 \%$ bounced. A small number of presses (mostly South African) have a presence on Facebook. Only four out of 52 have some form of open access publishing, usually journals. Only a small number offer price lists, catalogues, or other promotional material while, equally, 
merely a very small proportion offer online ordering facilities. Very few offer products in ebook formats at present. On a happier note, a good number of those presses currently active are now distributed overseas and their books are available through the Oxford-based African Books Collective, or one or two other distributors. Also on the positive side, the study shows that a significant proportion of the universities have established institutional repositories, and links to websites are indicated, where available.

As part of this project, African Minds have also created an interactive map of university presses in Africa that is continuously being updated. Users can either view the map by applying any of a number of filters, or download the full dataset at https://docs.google.com/spreadsheets/d/1URiTsMVkeM12D1ZT7IfxqcYgVEt0hohIi4xIy98 3FI8/edit\#gid=0.

Veldsman, Susan, and Ina Smith The Current Publishing Landscape in South Africa. http://www.slideshare.net/inaviljoensmith/south-african-scholarly-publishing-landscape (Posted 16 July 2016) [06/09/16]

A comprehensive inventory of the current South African scholarly (primarily journal) publishing landscape in the form of a 98 page SlideShare presentation. It sets out the Academy of Science of South Africa's http://www.assaf.org.za/ goals and initiatives, its policies, its scholarly publishing programme, accredited scholarly journal titles, the process of peer-review of journal titles, and journal publishers/publishing in South Africa. Additionally, it inventorizes ongoing projects, author support, requirements of high-quality journals, developing capacity in terms of scholarly writing, editing, reviewing, journal publishing needs and systems, indexing of journal titles, registering for indexing, measuring journal impact, tutorials, marketing and training, and more.

\section{Scientific, technical and medical publishing (see also $\rightarrow$ Scholarly publishing)}

Crewe, Robin M. “The Essence of Scholarship: Charting a Path Through the Thickets of

Scholarly Publishing." South African Journal of Science 112, nos. 3-4 (March/April 2016)

http://sajs.co.za/essence scholarship-charting-path-through-thickets-scholarly publishing/robin-m-crewe

A commentary on the work that has been done in South Africa to enhance the reputation of local scholarly journals, and a range of initiatives that have been launched in the past by groups of academics and learned societies to establish journals as vehicles for scholarly communication. Two local interventions have played a crucial role in the lives of scholars who are intent on having their work published and establishing their reputations: The first of these was the introduction by the Foundation for Research Development (ancestor of the current National Research Foundation/NRF) of a rating system for individual scholars in 1985. The rating of individuals was based on peer review of their scholarly contributions to their disciplines. The ratings essentially assessed whether they were recognised by their peers as falling in the broad categories of being international leaders in their fields, being recognised internationally for their contributions, or being recognised nationally. The second intervention was the change to a funding framework for universities in 2003 that provided an output subsidy for scholarly publications in journals, conference proceedings and books. For universities, maximising the number of these outputs was an important 
source of income, while for the government department providing the funding, this was meant as an incentive to enhance research performance, but with quality criteria built into the recognition of these outputs.

\section{Women in African publishing/Publishing by and for women}

Abrams, Dennis ‘I Have To Make It Happen': Uganda's Newest Publishing House. http://publishingperspectives.com/2016/06/uganda-publishing-house-nayanakkakoma/\#.V7wFU_krJD8 (Posted 09 June 2016) [18/06/16]

Nyana Kakoma, blogger and new mother, is also Uganda's newest publisher. Her company Sooo Many Stories http://somanystories.ug/publishing-house has plans to publish fiction and creative nonfiction. Started as a literature blog in 2014, the new company recognises the need to become a part of changing Uganda's poor reading culture.

Afroelle Magazine Bahati Books on their Role in Digital Revolution in Africa. http://www.afroellemagazine.com/bahati-books-on-their-role-in-digital-revolution-inafrica/ (Posted 01 August 2016) [29/12/16]

Founded by Kenyan born Barbara Njau and Kudakwashe Kamupira from Zimbabwe, Bahati Books, based in Mombasa http://bahatibooks.com/, is an e-book publishing company that publishes contemporary and classic African literature, and was created "to showcase diverse narratives of global African voices." This is an interview with the co-founders, in which they talk about what inspired them to start their business, their authors and the nature of their initial list, the challenges they faced in setting up their publishing house, and their views on current reading trends and patterns of contemporary African writing. (See also a Smart Monkey video interview with them at https://www.youtube.com/watch?v=51S0CqER8_k, and another at https://www.youtube.com/watch?v=xwOqiagGSco.)

Beautement, Tiah 'You Do Not Have to Have Big Offices in a Big Building to Have a Publishing House.' An Interview with Nyana Kakoma.

http://shortstorydayafrica.org/news/an-interview-with-nyana-kakoma (Posted 14

September 2016) [22/09/16]

Nyana Kakoma is a Ugandan writer, editor, blogger and publisher. She created the online platform Sooo Many Stories to promote and showcase Ugandan literature, and which has now grown into a full-blown publishing house http://somanystories.ug/publishing-house. In this interview she speaks about her beginnings, her new publishing house, and the challenges of distributing and marketing her list.

Trévien, Claire 'Making Rain': In Conversation with Colleen Higgs. http://sabotagereviews.com/2016/01/20/making-rain-in-conversation-with-colleen-higgs/ (Posted 20 January 2016 [16/02/16]

An interview with the founder of Modjaji Books http://www.modjajibooks.co.za/, an independent feminist press that publishes southern African women writers, and aims to fills a gap by providing a platform for serious and ground-breaking writing by new and established women writers "with brave voices." Modjaji have also built up a strong list in the poetry sector, and Colleen Higgs talks about the challenges of publishing poetry and dealing with a very substantial number of poetry submissions they receive each year, so 
many in fact that they have had to suspend considering further submissions, temporarily at least.

\section{BOOK INDUSTRY TRAINING/SELF-PUBLISHING}

\section{Articles and reports}

Crabbe, Richard "Training Opportunities for African Publishers." In Coming of Age. Strides in African Publishing. Essays in Honour of Dr. Henry Chakava at 70, Nairobi: East African Educational Publishers, 2016, 236-255.

Richard Crabbe, a former Chair of the African Publishers Network in its early years and now with the World Bank, says that his contribution in this collection focuses on the publishing industry rather than publishers, to emphasise the synergy that should exist among all players that are involved in the book chain: writers, editors, illustrators, designers, publishers, printers, distributors, and booksellers. "It is the failure to think in such terms that has led to book provision programmes side-lining one group or other, but especially distributors and booksellers." He presents a useful inventory of what has been done in the past, describes what is being done currently in terms of training opportunities and professional skills development programmes, and suggests how the African publishing industry and interested parties might prepare to equip a new generation of publishing professionals for the continent. In his conclusion Crabbe states "much has been done in the past; quite a bit is being done now, but we need to do more and better", in order to be "better able to project Africa's future publishing needs and identify the human resources that will be required to meet such needs."

\section{Training manuals and resources}

Borgstrom, Lionel "Teaching Publishing as Information Technology: A Description of a Structural Editing Curriculum at a South African University." Journal of Scholarly Publishing 47, no. 4 (July 2016): 328-335.

http://www.utpjournals.press/doi/abs/10.3138/jsp.47.4.328 (subscription based/pay per view) [13/08/16]

Since 2000, the Department of Information Science at the University of Pretoria has hosted a

Bachelor of Information Science programme specializing in publishing http://www.up.ac.za/information-science/article/1821944/bis-publishing. For the past ten years this has included a module focusing specifically on digital publishing. As traditional publishing becomes more digitized, the responsibilities of its professionals become increasingly distributed. This is especially true in situations where copy editors are required to work within a mark-up (increasingly XML) paradigm. In developing the curriculum at Pretoria, teaching of editorial practice was shaped to consistently reinforce the underlying structure of a publication, as inferred from the technology and practices of a production department. As such, the philosophy of creating a publication from an informed structural perspective has become one of the key driving concepts, reinforced over the course of several modules in the department's degree and continuing professional development programmes. 


\section{Handbooks for authors and self-publishing}

Attwell, Arthur The Problem with Self-publishing.

https://medium.com/@arthurattwell/the-problem-with-self-publishing-

d5073a69ad61\#.e2sncwgs8 [10/05/16]

A thought-provoking article by South African entrepreneur and founder of Book Dash http://bookdash.org/ Arthur Attwell, who says what self-publishers lack is not skill, but the relationship between an author and a publisher. The value of having a publisher doesn't lie in their skills, but in their relationship to your book." That relationship is a very special one: when a publisher invests in an author's work, both parties are personally committed, first and foremost, to the success of the book." 'Creative control' is often touted as a reason to self-publish, Attwell says: "That's like choosing to be a single parent because you believe you'll do a better job on your own than with a committed partner. There are many good reasons to self-publish (it's faster and more profitable per sale, for instance) but creative control is not one of them."

Does that mean self-publishing is always a bad idea, and that self-published books will never be as good as published ones? "Of course not. There are many great self-publishers and, just as in marriages and parenting, there are lousy publishers - often too tired, broke, overstretched or inexperienced to do the job properly. And, anyway, finding a publisher can be one of life's great snipe hunts. But this remains: if your book doesn't have two independently minded parents, you will have to work much harder, and get much luckier, to make your book all it can be."

Morgan, Rachel Self-Publishing in South Africa. An Introduction.

http://rachel-morgan.com/selfpubsa/ [17/08/16]

A very useful series of blog posts that address self-publishing specifically from a South African perspective, intended for local writers looking to begin the self-publishing journey. The following posts are available at this time:

Introduction

Copyright, ISBNs \& Barcodes

Which Platforms to Publish Your Books On

List of Local Formatters, Cover Designers, Illustrators, Editors \& More

ITIN, Tax \& How To Get Paid

How to Sell Print Books Locally

Marketing Ideas (forthcoming)

Continually Learning (forthcoming) 